\title{
Effects of environmental variability on trophic interactions and food web structure in a pelagic upwelling ecosystem
}

\author{
Richard D. Brodeur ${ }^{1, *}$, William G. Pearcy ${ }^{2}$ \\ ${ }^{1}$ Fisheries Research Institute, University of Washington, Seattle, Washington 98195, USA \\ ${ }^{2}$ College of Oceanography, Oregon State University, Corvallis, Oregon 97331, USA
}

\begin{abstract}
The dietary compositions of 18 species of pelagic nekton were examined from purse seine collections made during 4 (1981 to 1984) oceanographically contrasting summers in the coastal upwelling zone off Oregon and Washington, USA. Euphausiids, hyperiid amphipods, decapod larvae, pteropods, and larval and juvenile fishes were the dominant prey categories consumed during all years by this assemblage of nekton, although their relative proportions varied among the years. Considerable differences were observed in food habits, diet overlap, and food web structure depending upon the prevailing oceanographic conditions. The moderate to low upwelling year of 1981 showed a generally high overall trophic diversity and a low level of diet overlap and food web complexity. During the relatively strong upwelling year of 1982 , euphausids were the dominant food consumed, resulting in high dietary overlap and low trophic diversity and food web complexity. During the warm and low productivity El Niño year of 1983, marked changes were observed in the taxonomic composition of the diet of many species. The diets contained many species of southern origin leading to a high diversity of prey and low overall dietary overlap. A late occurrence of strong upwelling in 1984 resulted in a trophic diversity and overlap that were intermediate to the other years. Although some species preyed on species of lower trophic level during strong upwelling conditions, the overall trophic level was lowest during 1983 and 1984 due to the influx of large numbers of pelagic zooplanktivores.
\end{abstract}

\section{INTRODUCTION}

Trophic interactions occurring in pelagic coastal ecosystems of temperate upwelling regions are poorly understood. This is rather surprising in light of the high biomass and fishery production which characterize these regions (Ryther 1969). There is presently some debate as to how different these ecosystems are compared to other mid-latitude ecosystems with respect to overall productivity and trophodynamics (Cushing 1971, Barber \& Smith 1981). Walsh (1981) has estimated that both primary production and fish yield were virtually identical in the upwelling ecosystem off Oregon and the non-upwelling system off the East Coast of the USA; both these areas were substantially

\footnotetext{
- Present address: Alaska Fisheries Science Center, National Marine Fisheries Service, 7600 Sand Point Way NE, Seattle, Washington 98115-0070, USA
}

less productive than the upwelling system off Peru. Despite some similarities among them, there appears to be no 'typical' upwelling ecosystem due to complexities in the physical, chemical and biological interactions occurring within each system (Barber \& Smith 1981).

Spatial and temporal distributions of the standing stocks of the lower trophic levels in the coastal upwelling regime off Oregon and Washington in the Northeast Pacific have been studied, including those for primary producers (Anderson 1964, Small \& Menzies 1981), primary consumers such as zooplankton (Lorz \& Pearcy 1975, Lough 1975, Peterson \& Miller 1975, 1977. Landry \& Lorenzen 1989, Brodeur 1990) and ichthyoplankton (Richardson \& Pearcy 1977, Shenker 1988), as well as intermediate-level predators such as macrozooplankton and micronekton (Laurs 1967. Day 1971, Pearcy 1976, Shenker 1984, 1988). However, the utilization of the lower trophic levels by higher-level pelagic 
predators in this system is not well known except for a few predator species. Knowledge is needed about energy pathways to the entire assemblage of predators as a requisite to understanding trophic interactions and estimating food requirements of fish populations.

Biological processes occurring in the neritic region along the Oregon and Washington coasts are strongly affected by environmental conditions. Coastal upwelling, the dominant physical process throughout the study area, generally occurs episodically between April and September, with 4 or 5 major and several minor upwelling events occurring in a typical upwelling season (Huyer 1976, Hickey 1989). The timing and intensity of these events may strongly affect localized phytoplankton productivity and biomass (Small \& Menzies 1981), frontal structure, and the inshore-offshore location of zooplankton concentrations (Laurs 1967, Peterson \& Miller 1975). The physical and biological interactions within this ecosystem have been intensively studied (Landry \& Hickey 1989).

The purpose of the present study was to analyze the trophic relationships among common co-occurring pelagic predators in coastal waters off Washington and Oregon. Interannual variability in the species composition and diets of upper-trophic-level predators and food web structure was examined in relation to hydrography and biological productivity during 4 consecutive yet highly contrasting summers. The first year examined (1981) was one of relatively low upwelling intensity, yet was not atypical in terms of the nektonic species composition (Brodeur \& Pearcy 1986). A shift from above-average upwelling conditions and high productivity during the second year (1982) to a major warming event and a much reduced productivity regime during the following year (1983) resulted in a complete shift in the abundance and distribution patterns of the dominant nektonic species (Pearcy et al. 1985, Brodeur \& Pearcy 1986). This warming trend resulted from one of the strongest El Niño events ever recorded in the region, which began in the fall of 1982 and peaked during the summer of 1983, greatly altering physical and biological conditions throughout much of the Northeast Pacific (Mysak 1986) The last year (1984) witnessed some lingering effects of the El Niño on the composition of nekton but changes in several oceanographic variables (sea level, upwelling intensity) signaled the physical subsidence of the event (Pearcy \& Schoener 1987).

In this report, we describe in detail these interannual variations in environmental conditions and how they subsequently affected the species composition and diets of the dominant nektonic species and the trophic similarity among these species. Finally, we evaluate the relative importance of the dominant prey taxa in the different trophic levels to the upper-level food web for each of the 4 years.

\section{METHODS}

This study is based primarily on data collected during 8 cruises conducted during May and June of 1981 through 1983 and June and July of 1984 to study the early life history of salmon Oncorhynchus spp. in the coastal ocean off Oregon and Washington. Small-mesh (32 $\mathrm{mm}$ stretched) pelagic purse seines were used to quantitatively sample large volumes (up to $10^{6} \mathrm{~m}^{3}$ ) of seawater. The seine nets used were $495 \mathrm{~m}$ long and sampled the upper 30 to $65 \mathrm{~m}$ of the water column. Purse seines were set at designated stations along parallel transect lines $37 \mathrm{~km}$ apart between northern Washington and southern Oregon. The transects extended from 6 to $56 \mathrm{~km}$ from the coast. Altogether, 469 quantitative round-haul sets were made during these 8 cruises. The majority $(92.5 \%)$ of these sets were made during daylight hours. Additional sampling detail and catch information are given in Brodeur \& Pearcy (1986) and Pearcy \& Fisher (1990).

Data on surface temperature, salinity, and phytoplankton standing stock (measured as chlorophyll a) were collected at every station to relate these variables to the abundance and distribution patterns of the predators and their prey. A detailed analysis of the distribution of these oceanographic variables for each of the 8 cruises is presented in Brodeur \& Pearcy (1986). These distributions were similar between May and June from 1981 to 1983 and June and July of 1984; therefore the June data will be used in this paper to illustrate the major changes in oceanographic conditions among the 4 years.

Juvenile salmon ( $<1$ ocean year) were anesthetized and quickly frozen at sea and a random subsample of 10 stomachs per species per set were removed and preserved in the laboratory. Stomachs of older salmon ( $\geq 1$ ocean year) and large individuals of non-salmonid species were removed at sea from a random subsample of the catch and preserved in a formalin-seawater mixture in individually marked bags or jars. Smaller non-salmonid specimens were preserved whole at sea and their stomachs were later excised in the laboratory. Generally, a maximum of 5 stomachs per species per set of these associated species were examined, except in the sets where these species were particularly abundant, in which case up to 10 stomachs were examined.

Stomach contents were sorted and prey were identified to the lowest discernable taxa and life history stages, and then the gravimetric proportions of all taxa were recorded. Since a detailed taxonomic description of the prey of all predators is beyond the scope of this study and is presented elsewhere (Brodeur et al. 1987. Brodeur \& Pearcy 1990, Pearcy et al. 1990), the diets are described herein mainly in terms of higher taxonomic categories (ordinal level and above) for a broad 
Table 1. Major taxonomic categories used in the analysis of interannal variations in pelagic nekton diets

\begin{tabular}{|c|c|c|}
\hline Prey categ. & Abbrev. & Dominant taxa represented \\
\hline Cnidarians & CNID & Hydromedusae, Scyphomedusae \\
\hline Ctenophores & CTEN & Beroesp. \\
\hline Polychaetes & POLY & Tomopteris sp.. Pelagagobia sp. \\
\hline Pteropods & PTER & Limacina helicina, Clionidae \\
\hline Cephalopods & $\mathrm{CEPH}$ & Loligo opalescens, Gonatidae \\
\hline Copepods & COPE & $\begin{array}{l}\text { Neocalanus cristatus, } \\
\text { N. plumchrus }\end{array}$ \\
\hline Amphipods & AMPH & $\begin{array}{l}\text { Hyperoche medusarum, } \\
\text { Themisto pacifica, Vibiliidae }\end{array}$ \\
\hline Euphausiids & EUPH & $\begin{array}{l}\text { Euphausia pacifica, Thysanoessa } \\
\text { spinifera, Nyctiphanes simplex }\end{array}$ \\
\hline Decapods & DECA & Cancer spp., Pinnotheridae \\
\hline Insects & INSE & Diptera, Hymenoptera \\
\hline Chaetognaths & CHAE & Sagitta elegans \\
\hline Thaliacians & THAL & Caranaria japonica, Salpa sp. \\
\hline Clupeids & CLUP & Engraulis mordax, Clupea pallasi \\
\hline Scorpaenids & SCOR & Sebastes spp., Cottidae \\
\hline Pleuronectids & PLEU & $\begin{array}{l}\text { Parophrys vetulus, Psettichthys } \\
\text { melanostictus, Cithanichthys spp. }\end{array}$ \\
\hline Other fishes & OTHER & $\begin{array}{l}\text { Ammodytes hexapterus, } \\
\text { Ronquilus jordani. Osmeridae, } \\
\text { Hexagrammidae }\end{array}$ \\
\hline
\end{tabular}

overview of prey utilization (Table 1). Stomach contents were analysed for a total of 2663 specimens of 5 species of juvenile salmonids and 13 species of cooccurring epipelagic nekton, including adult salmonids and non-salmonids (Table 2). All but one (Loligo opalescens) were vertebrates and most were teleost fishes.

Diet overlaps matrices were computed separately for each year for all species for which 10 or more stomachs were examined and found to contain recognizable food. Similarities in diet were computed using an index modified from Schoener's (1970) index of similarity:

$$
\begin{aligned}
& \text { Percent similarity index }(\mathrm{PSI})= \\
& \qquad\left[1.0-0.5 \sum_{i=1}^{5}\left|P_{i j}-P_{h j}\right|\right] \times 100
\end{aligned}
$$

where $P_{i j}=$ the proportion by weight of food category $j$ in the diet of species $i_{i} P_{h j}=$ the proportion by weight of food category $j$ in the diet of species $h_{\text {; }}$ and $s=$ the number of resource categories. This index ranges from 0 , when there is no overlap between the species, to 100 , when all prey items are in equal proportions, and it has been found to be independent of sample size

\begin{tabular}{|c|c|c|c|c|c|}
\hline \multirow{2}{*}{$\begin{array}{l}\text { Family } \\
\quad \text { Scientific name }\end{array}$} & \multirow[t]{2}{*}{ Common name } & \multicolumn{4}{|c|}{ No. stomachs examined } \\
\hline & & 1981 & 1982 & 1983 & 1984 \\
\hline \multicolumn{6}{|l|}{ Loliginidae } \\
\hline Loligo opalescens & Market squid & 43 & & & 17 \\
\hline \multicolumn{6}{|l|}{ Squalidae } \\
\hline Squalus acanthias & Spiny dogfish & 23 & 81 & 21 & 21 \\
\hline \multicolumn{6}{|l|}{ Clupeidae } \\
\hline Alosa sapidissima & American shad & 20 & & & \\
\hline Clupea pallasi & Pacific herring & & 11 & 27 & \\
\hline \multicolumn{6}{|l|}{ Engraulidae } \\
\hline Engraulis mordax & Northern anchovy & 18 & & & \\
\hline \multicolumn{6}{|l|}{ Salmonidae } \\
\hline Oncorhynchus nerka & Sockeye salmon (juvenile) & & 19 & & \\
\hline O. keta & Chum salmon (juvenile) & 10 & 15 & & \\
\hline O. kisutch & Coho salmon (juvenile) & 378 & 181 & 237 & 156 \\
\hline O. kisutch & Coho salmon (adult) & 33 & 47 & 30 & 35 \\
\hline O.tshawytscha & Chinook salmon (juvenile) & 95 & 233 & 122 & 81 \\
\hline O. tshawytscha & Chinook salmon (adult) & 11 & 26 & 22 & 14 \\
\hline O. clarki clarki & Cutthroat trout & 43 & 16 & 17 & \\
\hline O. mykiss & Steelhead & 27 & 33 & & \\
\hline \multicolumn{6}{|l|}{ Gadidae } \\
\hline Merluccius productus & Pacific hake & & 53 & & 66 \\
\hline \multicolumn{6}{|l|}{ Carangidae } \\
\hline Trachurus symmetricus & Jack mackerel & & 25 & 26 & 59 \\
\hline \multicolumn{6}{|l|}{ Scombridae } \\
\hline Scomber japonicus & Pacific mackerel & & & 54 & 85 \\
\hline \multicolumn{6}{|l|}{ Scorpaenidae } \\
\hline Sebastes melanops & Black rockfish & & 25 & 20 & 18 \\
\hline \multicolumn{6}{|l|}{ Anoplopomatidae } \\
\hline Anoplopoma fimbria & Sablefish & 35 & & 18 & 16 \\
\hline TOTAL & & 726 & 760 & 609 & 568 \\
\hline
\end{tabular}

Table 2. Total number of stomachs of pelagic nektonic species examined off Oregon and Washington from 1981 to 1984 
(Kohn \& Riggs 1982). Only prey exceeding $0.1 \%$ of the total weight of the diet of a particular predator were used in the calculations. Overlaps $>60$ were considered significant in this analysis.

As measures of dietary overlap are sensitive to the level of taxonomic resolution used (Greene \& Jaksic 1983), the generic or specific taxonomic levels were used in calculating overlap values. The only exceptions to this were in the case of a few meroplanktonic prey taxa such as fish and decapod larvae which were grouped into families due to their short temporal existence in the plankton and the problems of identifying many closely related species

Trophic level assignments (TLA's) were calculated for each species for each year using the formula proposed by Mearns et al. (1981):

$$
\mathrm{TLA}=1+\sum_{n=1}^{s}\left(K_{n} \times I_{n}\right)
$$

where TLA = trophic level assignment of a consumer (range $=2$ to $>5$ ) $K_{n}=$ trophic level assignment of prey item ' $\mathrm{n}$ ' (range $=1$ to 5); $I_{n}=$ proportion of diet made up by prey item ' $\mathrm{n}$ '; and $s=$ number of prey categories. The $I_{n}$ values were derived from the proportion of the total biomass of a predator's diet made up by a particular prey taxon for all collections combined from a particular year using the same taxonomic resolution that was used in the diet overlap measurements.

The trophic levels $\left(K_{n}\right)$ of many prey species are potentially difficult to assign due to the plasticity in feeding of many invertebrate species. A compilation was made of the known food habits for most of the prey species found in the study using data from the literature. Among the more important sources of information on food habits were Laurs (1967), Simenstad et al. (1979), Mearns et al. (1981), Yang (1982), and Turner (1984).

The conventional trophic level hierarchy $(1.0=$ primary producers, $2.0=$ herbivores, $3.0=$ primary carnivores, $4.0=$ secondary carnivores, $5.0=$ tertiary carnivores) was followed in this study (Mearns et al. 1981). Many species exhibit several feeding modes (Parsons \& LeBrasseur 1970) and thus intermediate (i.e. non-integer) trophic levels were assigned to these species. Trophic levels of prey species were held constant for all years due to a lack of data on how they were affected during the variable environmental conditions (see 'Discussion')

\section{RESULTS}

\section{Physical and biological environment}

Upwelling intensity [based on the Bakun upwelling index for $45^{\circ} \mathrm{N}, 125^{\circ} \mathrm{W}$ (data from Bakun 1975, Mason \& Bakun 1986, A. Bakun unpubl.)J was well below the long-term (1967 to 1989) average up to the time of our sampling during 1981 (Fig. 1). Conversely, upwelling was very strong in May and June 1982, with several strong upwelling events occurring just prior to and during our sampling. Upwelling was generally above average during the early summer of 1983 . However, a deep thermocline, attributable to the very strong El Niño - Southern Oscillation event occurring that year, resulted in warm and nutrient-poor water at the surface even though the winds were favorable for upwelling (Brodeur et al. 1985, Huyer \& Smith 1985). Upwelling began late during 1984, but was intense during our sampling periods. In terms of cumulative upwelling for the late spring and early summer months included in this study, 1982 showed above-average upwelling, 1983 was close to average conditions, 1981 exhibited belownormal upwelling conditions and 1984 showed poor upwelling during May but strong upwelling in June and July, resulting in above-average intensity (Fig. 1).

Surface temperature, salinity and chlorophyll a isopleths for all 8 cruises were presented by Brodeur \& Pearcy (1986). Data for the June cruises show high surface temperatures in 1981 and again in 1983, whereas the low inshore temperatures typical of summer upwelling regimes were measured in June 1982 (Fig. 2). Sea surface temperatures during June 1984 were cold inshore but warmer temperatures were found offshore of Oregon (Fig. 2), possibly indicative of Columbia River discharge (Landry et al. 1989).

Surface temperature-salinity envelopes provided evidence that different water masses may have been

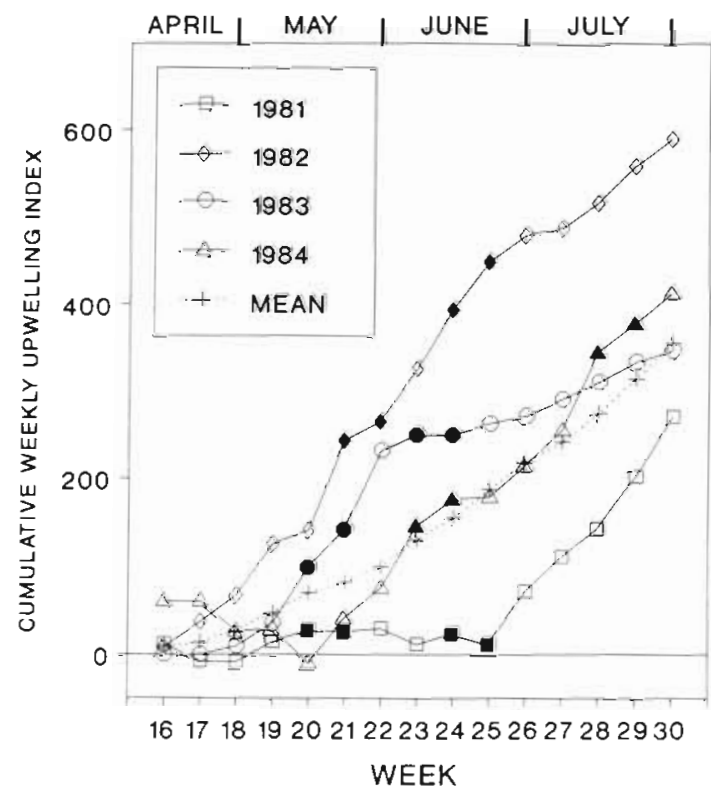

Fig. 1. Cumulative weekly upwelling indices for 1981 to 1984 and the long-term (1967 to 1989) mean for each week at $45^{\circ} \mathrm{N}, 125^{\circ} \mathrm{W}$. The weeks were standardized so that Week 1 of all years started on January 1 The filled points represent the approximate weeks of our sampling 


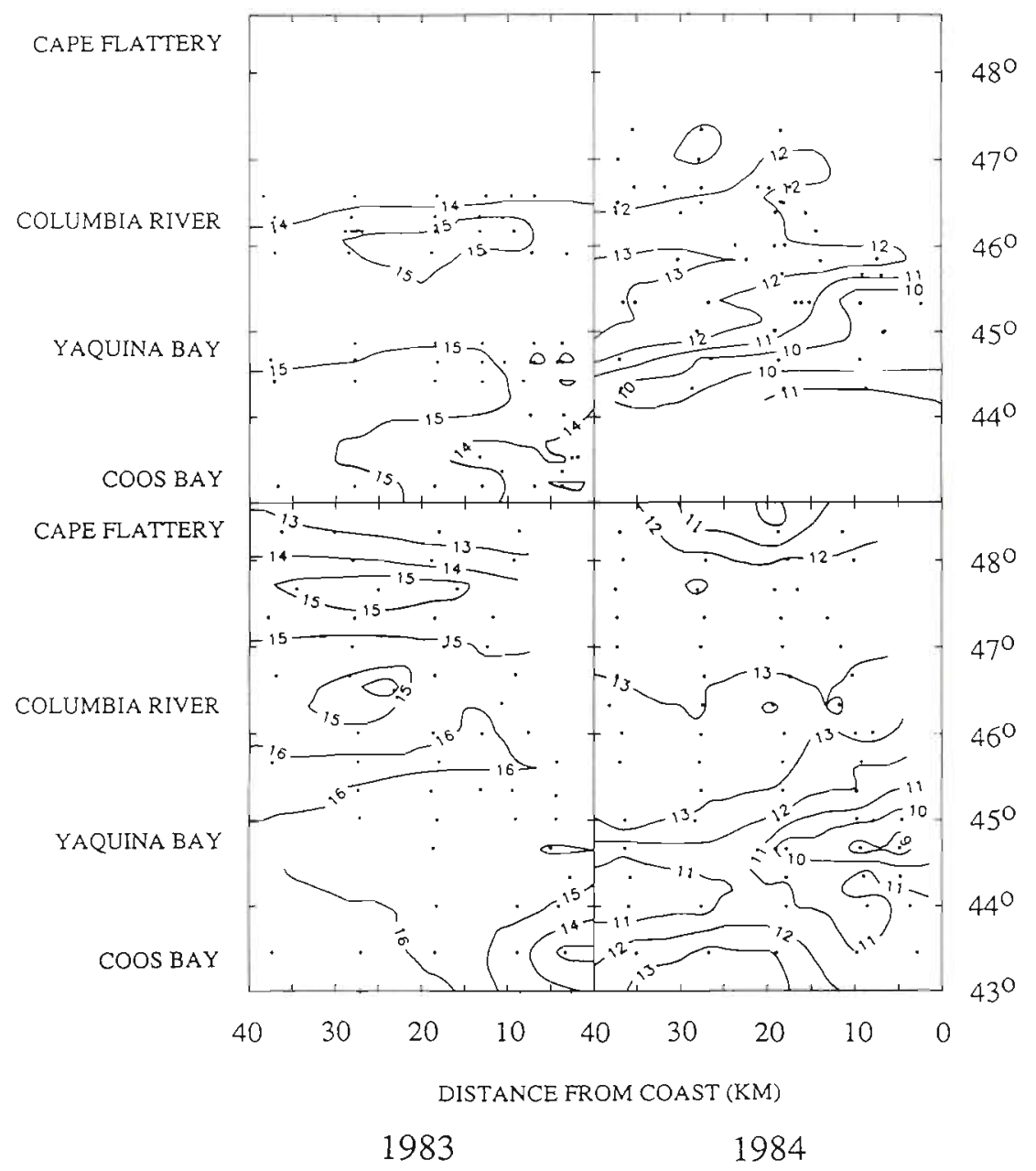

Fig. 2. Surface temperature isopleths $\left({ }^{\circ} \mathrm{C}\right)$ for the June cruises from 1981 to 1984

present during the successive June cruises (Fig. 3A). Cold temperatures and high salinities typical of newly upwelled water were predominant at the surface during June of 1982 and 1984. Warmer and less saline water was prevalent during 1981 and 1983 (Fig. 3A).
Subsurface $(10 \mathrm{~m})$ temperature-salinity envelopes, measured by CTD casts at all stations (no CTD data were available for 1981), showed a similar pattern to that found at the surface for 1982 and 1983, but a much broader range of temperature values was found during
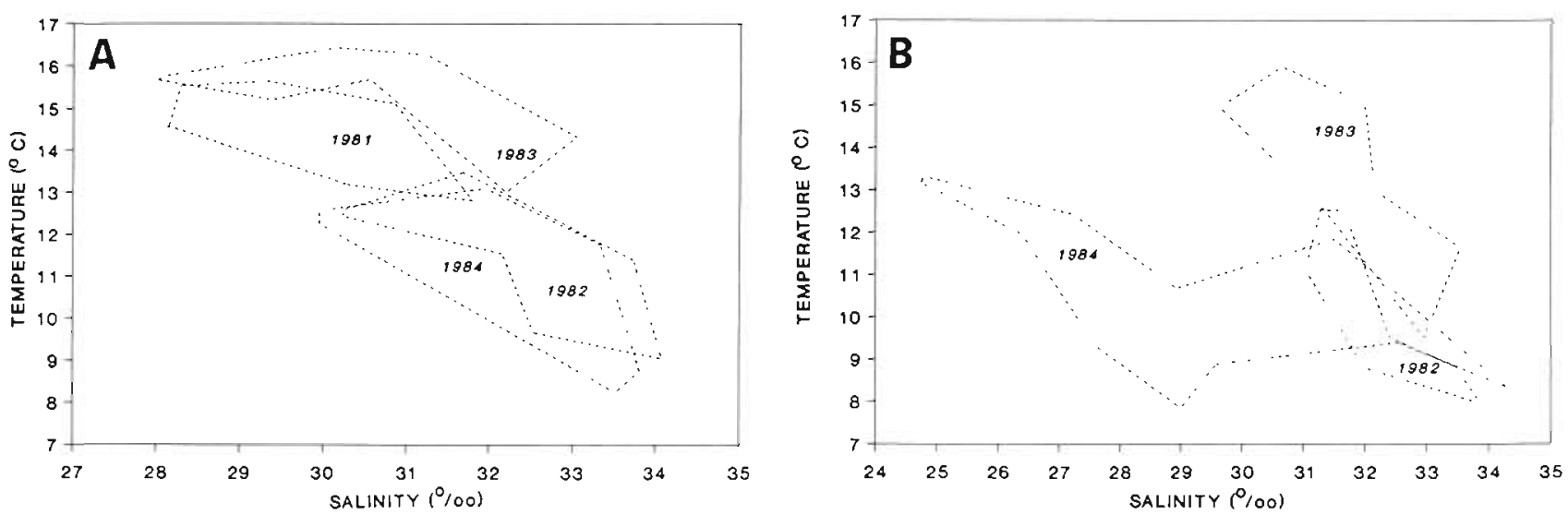

Fig. 3. (A) Surface and (B) $10 \mathrm{~m}$ temperature-salinity envelopes for the June cruises 


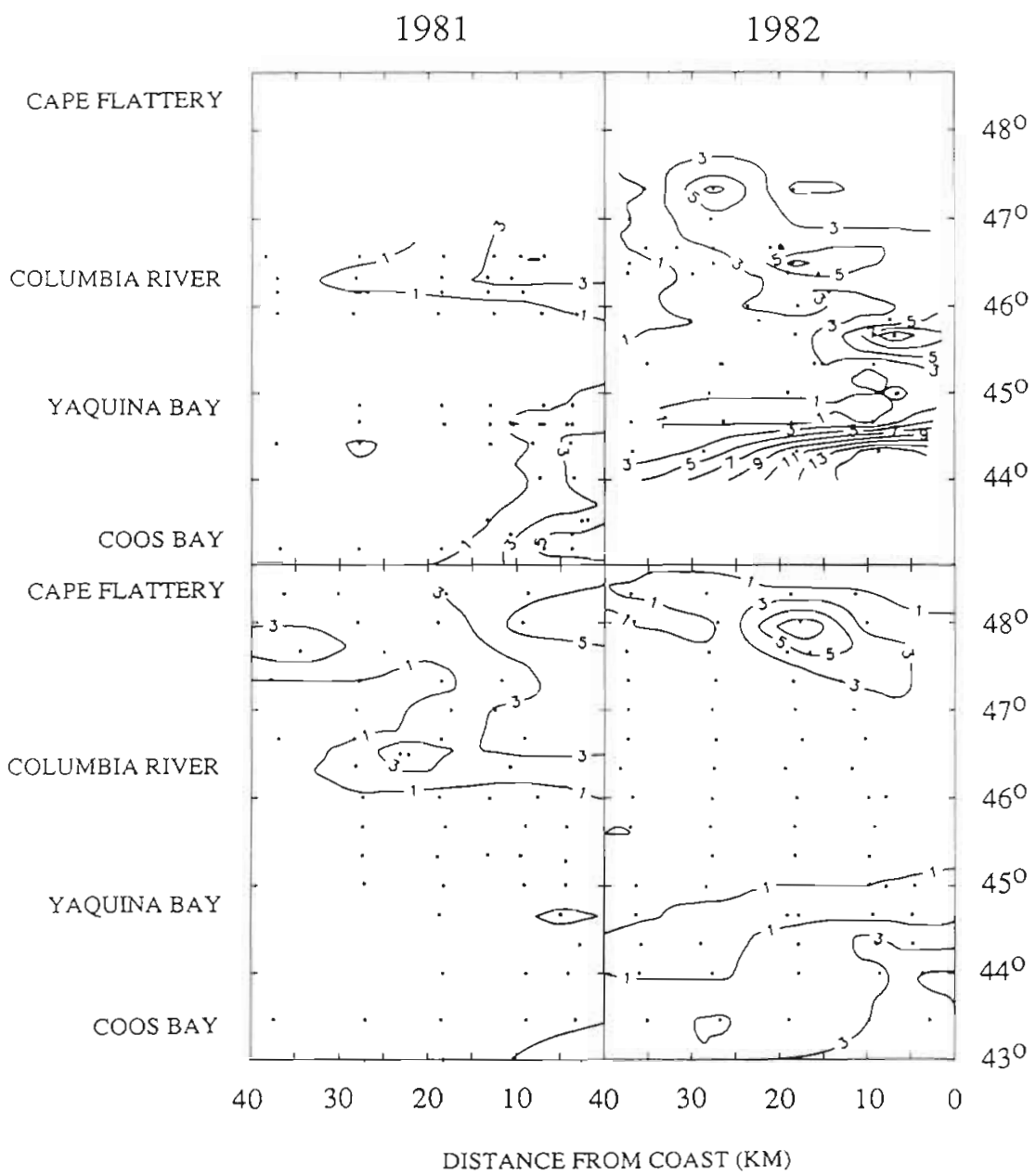

1983
Fig. 4. Surface chlorophyll a isopleths $\left(\mu \mathrm{g}^{-1}\right)$ for the June cruises from 1981 to 1984
1983 (Fig. 3B). Both newly upwelled water and lowsalinity, warm water were found during 1984. Since this latter water mass was not observed in surface measurements, it is likely to be associated with a subsurface core of the Columbia River plume.

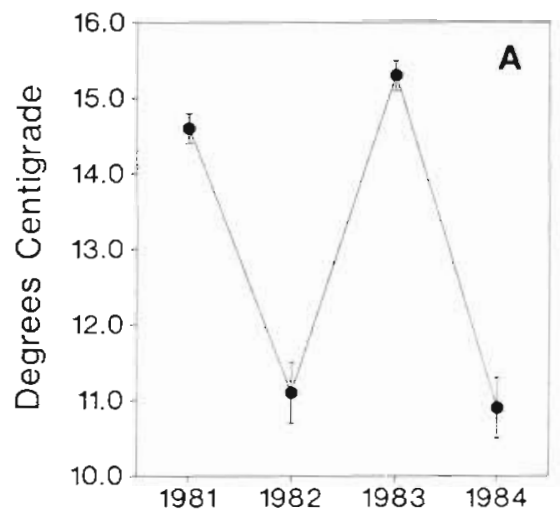

Surface chlorophyll a concentrations measured during the June cruises were generally high during 1982, extremely low in 1983, and intermediate in 1981 and 1984 (Fig. 4). A subsurface chlorophyll peak was observed in summer 1983, and chlorophyll profiles

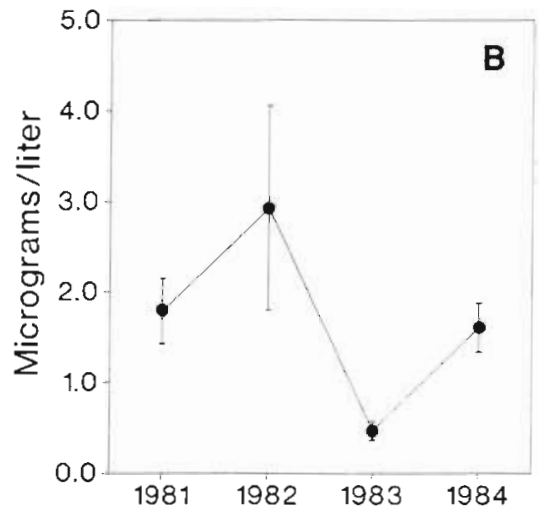

Fig. 5. Comparison of the mean ( \pm SD) surface temperature (A) and chlorophyll concentrations (B) for stations occupied off Oregon for the June cruises of each year 
that year resembled those of non-upwelling periods for much of the summer (Miller et al. 1985).

Overall mean temperatures and chlorophyll a levels in June for stations only in the area $\left(47^{\circ}\right.$ to $\left.44^{\circ} \mathrm{N}\right)$ common to all 4 years exhibited a typical inverse pattern expected in an upwelling environment (Fig. 5). Surface temperatures were slightly below the long-term mean temperatures for June (ca $12{ }^{\circ} \mathrm{C}$; Landry et al. 1989) during 1982 and 1984 but well above the mean during 1981 and 1983. Chlorophyll a concentrations during 1984 were lower than expected, based on upwelling intensity, which may be due either to the delayed onset of the upwelling season caused by the waning El Niño or to upwelling of nutrient-poor subsurface water. reported for nekton off Washington and Oregon during summer 1983 (Pearcy \& Schoener 1987). A relatively mixed fauna occurred during June and July of 1984 , with both northern (sablefish Anoplopoma fimbria, spiny dogfish, and Pacific herring) and southern (Pacific and jack mackerel and northern anchovy) species found in abundance. Sablefish were represented entirely by 0 -group pelagic juveniles which were generally abundant later in the year (Brodeur \& Pearcy 1986). The later sampling dates during 1984 could have accounted for the higher abundances of this species compared with the previous years.

It has been reported previously that there were some interannual differences in the inshore-offshore distributions of several nektonic species, especially during the 1983 El Niño (Pearcy et al. 1985). We examined this by categorizing the occurrences of the dominant species as being either inshore $(<18 \mathrm{~km})$,

The catches in the early summer of all 4 years were comprised almost entirely (>98\% of the total abundance) of 2 salmonid (coho and chinook salmon) and 8 non-salmonid taxa (Fig. 6). Another abundant species during most years of the sampling, Pacific saury Cololabis saira, occurred mainly during the late summer and early fall (Brodeur \& Pearcy 1986) and was not important during the period considered in this analysis.

During 1981 the nektonic fauna was dominated ( $>89 \%$ ) by market squid Loligo opalescens and northern anchovy Engraulis mordax, both of which occur and spawn in the study area but have centers of abundance off California. Rockfishes Sebastes spp., represented by several different species, were mostly late juveniles and were abundant off Oregon during 1981 (Fig. 6). Although squid Loligo opalescens was again the dominant species collected during 1982, there was also a marked shift in species composition toward species with northern affinities (spiny dogfish Squalus acanthias, Pacific herring Clupea pallasi, and salmonids Oncorhynchus spp.) or species which migrate through the study area (e.g. Pacific hake Merluccius productus) as adults.

The El Niño year of 1983 saw a dramatic shift in species composition from Loligo opalescens and spiny dogfish to warmwater species (e.g. Pacific mackerel Scomber japonicus, jack mackerel Trachurus symmetricus and northern anchovy; Fig. 6). Many distributional anomalies were
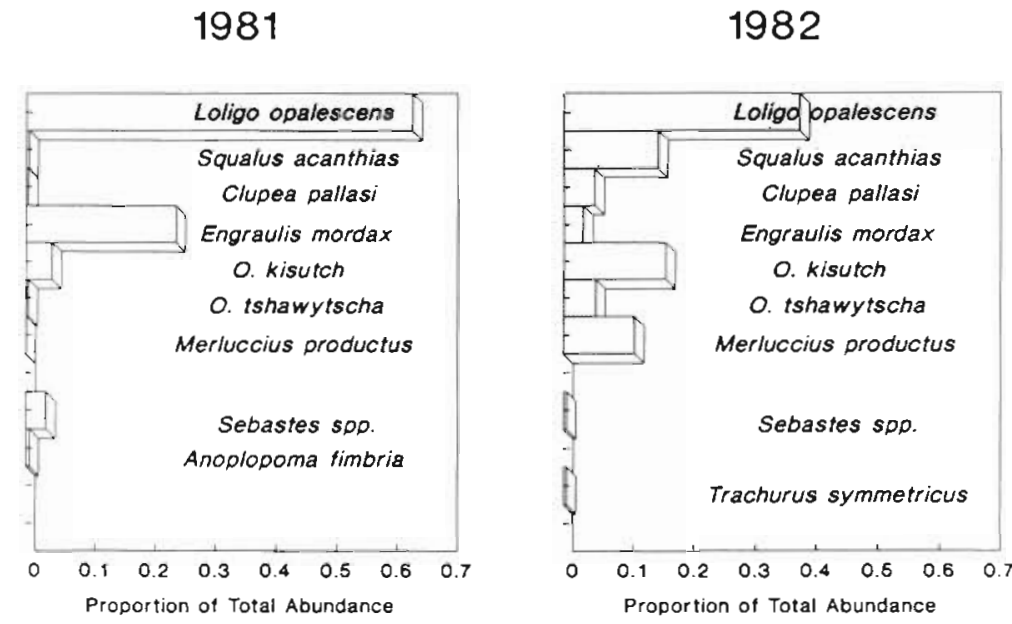

1983
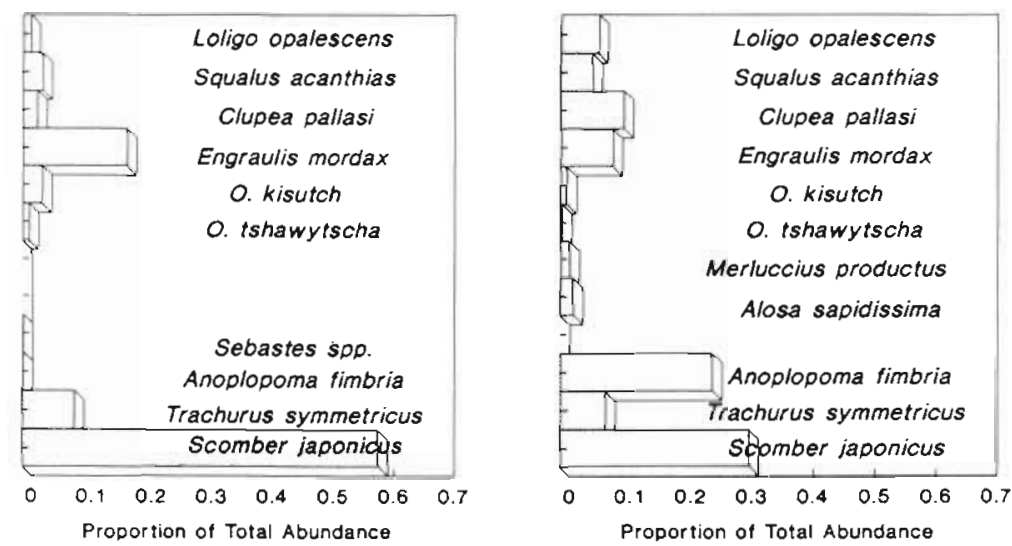

Fig. 6. Relative abundance of the 12 most abundant nektonic species collected during May and June of 1981 to 1983 and June and July of 1984 in purse seine collections 

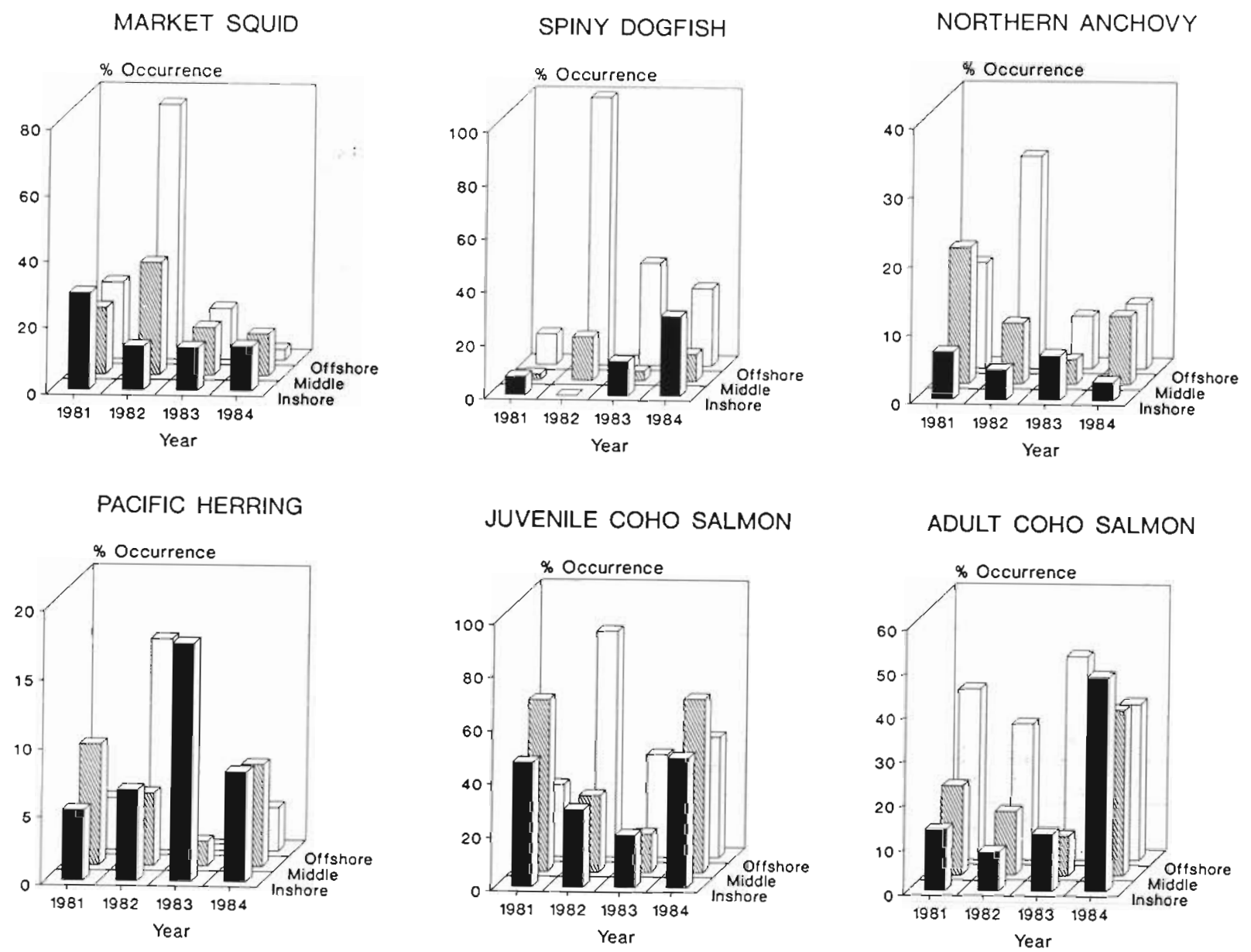

JUVENILE CHINOOK SALMON

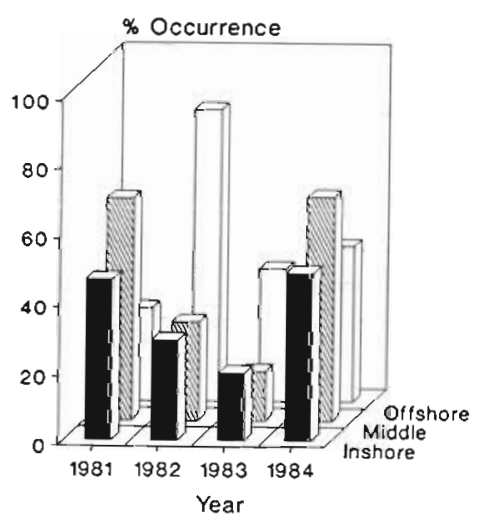

ADULT CHINOOK SALMON
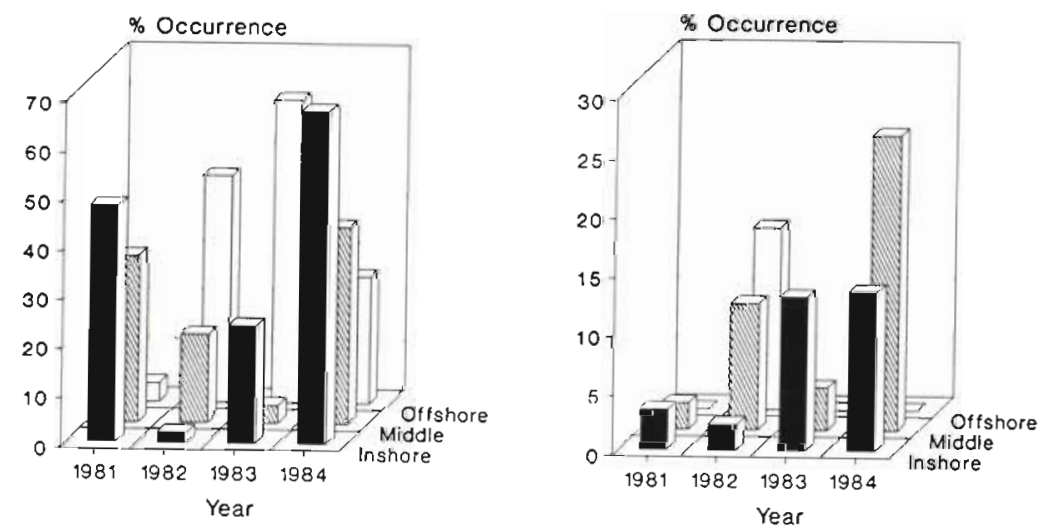

Fig. 7. Frequency of occurrence of the dominant salmonid and non-salmonid nektonic species in inshore $(<18 \mathrm{~km})$, mid-shelf (18 to $37 \mathrm{~km})$ and offshore $(\geq 37 \mathrm{~km})$ collections

mid-shelf (18 to $37 \mathrm{~km}$ ), or offshore $(\geq 37 \mathrm{~km}$ ) during each year. For all the species examined (Fig. 7), 1982 showed the same general pattern of the highest frequency of occurrence offshore and generally the lowest inshore. With some exceptions, the 1984 catches showed the opposite pattern of being skewed toward the inshore stations. Distributions were mixed during 1981 and 1983, with species showing both inshore- and offshore-skewed occurrence patterns or no pattern at all.

\section{Food habits and dietary overlap}

The diets were highly varied during 1981 and prey dominance for individual predator species was distributed among several of the major prey categories 
Table 3. Percent by weight of the major prey categories consumed by pelagic predators during 1981 See Table 1 for the prey codes listed. j: juvenile; a: adult

\begin{tabular}{|c|c|c|c|c|c|c|c|c|c|c|c|c|c|c|c|}
\hline \multirow[t]{2}{*}{ Predators } & \multicolumn{15}{|c|}{ Prey categories } \\
\hline & CNiD & PTER & CEPH & COPE & CIRR & AMPH & EUPH & DECA & INSE & CHAE & THAL & CLUP & SCOR & PLEU & OTHER \\
\hline Market squid & 1.1 & 0.1 & & 5.3 & & & 4.0 & 8.3 & & 67.0 & & & 1.0 & & 13.2 \\
\hline Spiny dogfish & 50.2 & & & & & & 0.2 & & & & & 19.1 & & 3.8 & 26.7 \\
\hline American shad & & & & 61.2 & & & 38.5 & 0.3 & & & & & & & \\
\hline Northern anchovy & & 45.0 & 0.5 & 13.1 & & 0.7 & 33.0 & 6.5 & & & & & & & 0.9 \\
\hline Coho salmon (j) & & 5.4 & 0.2 & 0.3 & & 0.6 & 5.8 & 10.1 & 0.2 & & & 2.1 & 41.3 & 2.4 & 31.6 \\
\hline Coho salmon (a) & 15.1 & 0.2 & 3.7 & & & & & 9.9 & & & & 70.4 & 0.8 & & \\
\hline Chinook salmon (j) & & 0.5 & 10.9 & 0.1 & & 0.1 & 2.6 & 5.2 & 0.3 & & & 9.9 & 21.4 & 7.1 & 41.8 \\
\hline Chinook salmon (a) & 0.4 & & & & & & & & & & & 98.2 & 0.2 & & 1.1 \\
\hline Cutthroat trout & & 0.2 & & & & & 0.4 & & & & & 59.9 & 14.3 & & 25.0 \\
\hline Steelhead trout & 0.7 & & 1.2 & 0.1 & 11.0 & 2.3 & 17.2 & 5.9 & 0.3 & & & & 41.3 & 2.4 & 17.6 \\
\hline Sablefish & 14.4 & 7.2 & & & & & 3.6 & 11.7 & & & 8.3 & & 34.8 & & 19.9 \\
\hline
\end{tabular}

(Table 3). Various invertebrate taxa were predominant in the diets of all non-salmonids except sablefish. Pteropods (mainly Limacina helicina) were a major food of the northern anchovy while several species of copepods were the dominant food of American shad. Squid Loligo opalescens and spiny dogfish had fairly stenophagous diets, consuming mainly chaetognaths and hydromedusae (primarily Velella velella), respectively (Table 3). Euphausiids were a secondary food source for most predators but were among the most commonly consumed prey. Juvenile and adult fishes were important in the diets of many species, especially the salmonids and sablefish. Most important among these were the northern anchovy Engraulis mordax, scorpaenids (Sebastes spp. and Hemilepidotus spp.), and Pacific sand lance Ammodytes hexapterus.

Overall, the diets during 1981 were dissimilar (mean PSI $=18.6)$. Only 3 high $($ PSI $\geq 60)$ overlap values occurred among the piscivorous salmonid species at the higher end of the trophic scale (Fig. 8). Adult coho and chinook salmon exhibited the highest overlap (PSI = 71), which was attributable mainly to the high consumption of Engraulis mordax juveniles and adults on the part of both predators.

In 1982, euphausiids were the dominant prey item in the diets of many of the predators (Table 4). Pacific herring, adult coho salmon, steelhead Oncorhynchus mykiss, and black rockfish Sebastes melanops all had
Fig. 8. Diet overlap matrix for 1981 containing only those species for which 10 or more stomachs were analyzed. The matrices were arranged by increasing trophic level to facilitate comparisons among similarly feeding species

\begin{tabular}{|c|c|c|c|c|c|c|c|c|c|c|c|}
\hline 1981 & 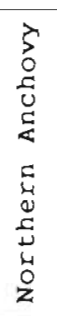 & 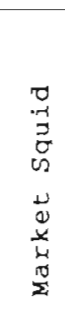 & 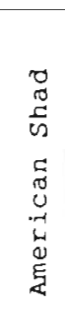 & 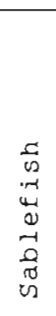 & 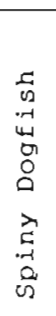 & 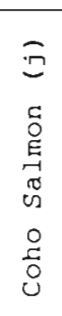 & $\begin{array}{l}\widehat{\pi} \\
5 \\
0 \\
\underline{1} \\
0 \\
0 \\
0 \\
0 \\
0 \\
0\end{array}$ & 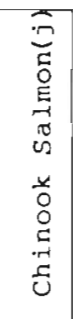 & 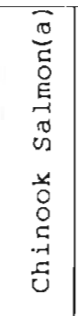 & 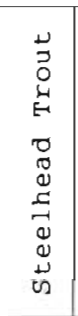 & 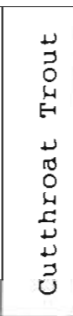 \\
\hline \multicolumn{12}{|l|}{ Northern Anchovy } \\
\hline Market Squid & 28 & --- & & & & & & & & & \\
\hline American Shad & 8 & 4 & ---- & & & & & & & & \\
\hline Sablefish & 6 & 1 & 4 & $\ldots$ & & & & & & & \\
\hline Spiny Dogfish & 16 & 13 & 0 & 34 & --- & & & & & & \\
\hline Coho Salmon (j) & 13 & 6 & 2 & 58 & 27 & $\cdots$ & & & & & \\
\hline Coho Salmon (a) & 20 & 7 & 0 & 16 & 33 & 6 & $\ldots$ & & & & \\
\hline Chinook Salmon $(j)$ & 4 & 0 & 1 & 43 & 36 & 53 & 14 & $-\infty$ & & & \\
\hline Chinook Salmon (a) & 17 & 16 & 0 & 1 & 19 & 1 & 71 & 9 & $\ldots--$ & & \\
\hline Steelhead Trout & 2 & 0 & 14 & 32 & 26 & 33 & 4 & 29 & 1 & ---- & \\
\hline Cutthroat Trout & 11 & 3 & 0 & 30 & 36 & 30 & 61 & 38 & 61 & 25 & \\
\hline
\end{tabular}


Table 4. Percent by weight of the major prey categories consumed by pelagic predators during 1982. See Table 1 for the prey codes listed. j: juvenile; a: adult

\begin{tabular}{|c|c|c|c|c|c|c|c|c|c|c|c|c|}
\hline \multirow[t]{2}{*}{ Predators } & \multicolumn{12}{|c|}{ Prey categories } \\
\hline & POLY & PTER & CEPH & COPE & AMPH & EUPH & DECA & INSE & CLUP & SCOR & PLEU & OTHER \\
\hline Spiny dogfish & & & 0.3 & & & 0.1 & & & 1.0 & & 12.3 & 86.3 \\
\hline Pacific herring & & & & & 4.1 & 95.5 & 0.4 & & & & & \\
\hline Sockeye salmon (j) & 1.3 & 3.2 & & 4.9 & 4.6 & 15.5 & 1.2 & & 4.3 & & & 65.0 \\
\hline Chum salmon (j) & & & & 34.6 & 6.9 & 48.8 & 8.9 & & & & & \\
\hline Coho salmon (j) & 0.2 & 0.3 & & 0.9 & 3.3 & 13.8 & 5.3 & 0.3 & 6.7 & 14.5 & 1.0 & 54.2 \\
\hline Coho salmon (a) & & 0.3 & 3.2 & & 0.1 & 59.8 & 5.8 & & 23.1 & 5.2 & & 2.6 \\
\hline Chinook salmon (j) & & 0.2 & 0.5 & & 0.1 & 9.0 & 3.1 & & 23.4 & 23.9 & 2.5 & 37.2 \\
\hline Chinook salmon (a) & & 0.2 & 0.6 & & & 46.7 & 0.6 & & 31.8 & 0.5 & & 19.6 \\
\hline Cutthroat trout & & & & & 0.1 & 1.3 & 0.4 & 0.3 & 1.0 & 13.2 & & 83.8 \\
\hline Steelhead trout & & & & & 2.6 & 61.7 & 1.2 & & 2.8 & 4.6 & & 27.1 \\
\hline Pacific hake & & & & & 0.3 & 23.7 & 0.3 & & 55.4 & 0.4 & & 19.9 \\
\hline Jack mackerel & & 1.0 & & & 0.1 & 14.1 & & & 70.6 & 0.7 & & 13.6 \\
\hline Black rockfish & & 0.2 & & & & 74.4 & 10.4 & & & 1.7 & 2.0 & 11.3 \\
\hline
\end{tabular}

a major part of their diets ( $>50 \%$ by weight) consisting of euphausiids (Euphausia pacifica and Thysanoessa spinifera), and most species showed a greater utilization of euphausiids in 1982 than 1981. Much of the rest of the diet for these and many of the remaining species consisted of several species of juvenile fishes (mainly Clupea pallasi, Engraulis mordax, Hemilepidotus spinosus, Sebastes spp. and Hexagrammos spp.). Cancer magister megalopae were also important components of the diets of several species.
The extensive use made of euphausiids during 1982 is reflected in the medium to high values seen in the overlap matrix (Fig. 9). Many of the lower-level planktivorous species had high overlap values due to the presence of similar proportions of the 2 common euphausiid species in their stomachs. Adult chinook salmon showed high overlaps (PSI = 73) with both adult coho and hake due to similar proportions of Euphausia pacifica, Thysanoessa spinifera and Engraulis mordax in their diets. The overall mean PSI (28.2) was the highest of the 4 years examined.

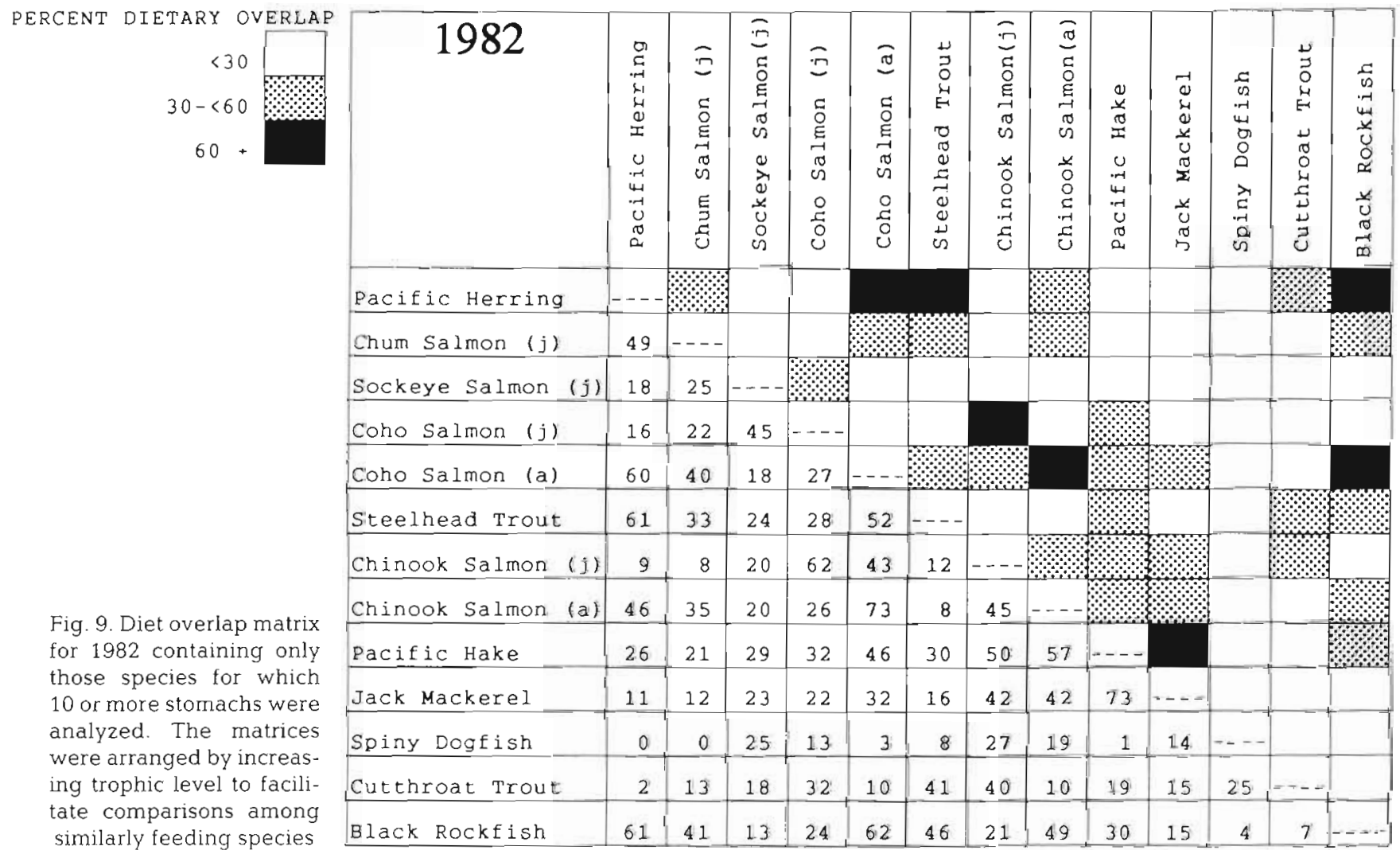


Table 5. Percent by weight of the major prey categories consumed by pelagic predators during 1983. See Table 1 for the prey codes listed. j: juvenile; a: adult

\begin{tabular}{|c|c|c|c|c|c|c|c|c|c|c|c|c|c|c|}
\hline \multirow[t]{2}{*}{ Predators } & \multicolumn{14}{|c|}{ Prey categories } \\
\hline & CTEN & PTER & CEPH & COPE & AMPH & EUPH & DECA & INSE & CHAE & THAL & CLUP & SCOR & PLEU & OTHER \\
\hline Spiny dogfish & 0.4 & & & & & 2.3 & & & & & 19.3 & & 31.2 & 46.8 \\
\hline Pacific herring & & & & 19.2 & 11.1 & 68.5 & & & & & & & & 1.2 \\
\hline Chum salmon & 0.6 & & & 5.9 & 1.5 & 19.0 & 1.2 & 0.9 & 55.3 & & 10.4 & 0.3 & & 4.3 \\
\hline Coho salmon (j) & & 0.6 & & 0.7 & 2.0 & 3.0 & 13.6 & 0.2 & & 0.6 & 2.2 & 26.5 & 6.3 & 43.6 \\
\hline Coho salmon & 0.1 & 0.1 & & & & 0.6 & 55.5 & & & & 36.0 & & 0.4 & 7.1 \\
\hline Chinook salmon (j) & & 1.0 & 0.7 & 0.5 & 0.2 & 1.1 & 10.4 & & & & 0.9 & 20.7 & 26.6 & 38.7 \\
\hline Chinook salmon & 0.1 & 0.1 & 1.6 & & & 13.9 & 3.6 & & & & 30.6 & 7.3 & 7.5 & 35.0 \\
\hline Cutthroat trout & & & & & & & 3.7 & 0.3 & & & 2.0 & 45.7 & & 48.3 \\
\hline Jack mackerel & & 1.3 & & 0.6 & 3.8 & 90.8 & 3.1 & & & & & & & 0.4 \\
\hline Pacific mackerel & & & & 0.8 & 0.1 & 88.9 & 0.7 & & & 7.3 & & 1.1 & 0.2 & 0.9 \\
\hline Black rockfish & 13.3 & & 0.1 & & & 3.3 & 18.1 & & & & 41.9 & & & 23.1 \\
\hline Sablefish & 0.3 & 0.7 & & & 6.7 & 5.5 & 3.9 & & & 76.1 & & & & 6.7 \\
\hline
\end{tabular}

No single prey category dominated the diets in 1983 as much as euphausiids did in 1982 (Table 5). Euphausiids composed the majority of the diet only in Pacific herring and Pacific and jack mackerel, but contributed little to the diets of the salmonid species. Demersal juvenile flatfishes were an important prey of spiny dogfish while many other fish taxa (especially Engraulis mordax) were consumed by the other predators. Cancer spp. megalopae were important components of the diets of juvenile and adult coho and black rockfish. Chaetognaths were the main component of the diet of chum salmon. Gelatinous zooplankton (i.e. salps and ctenophores) were more important in the diets of several species compared with 1982 .

The high diversity of vertebrate and invertebrate prey consumed by most of the epipelagic predators resulted in a low interspecific overlap for 1983 (mean PSI $=15.2$; Fig. 10). Only 10 of the 66 pairings $(15.1 \%)$ exhibited overlap values $>30$. The intermediate and high overlap values for higher trophic level fishes (salmonids, black rockfish and spiny dogfish) reflect the common utilization of similar species of fish prey.

Euphausiids were again important in the diets of

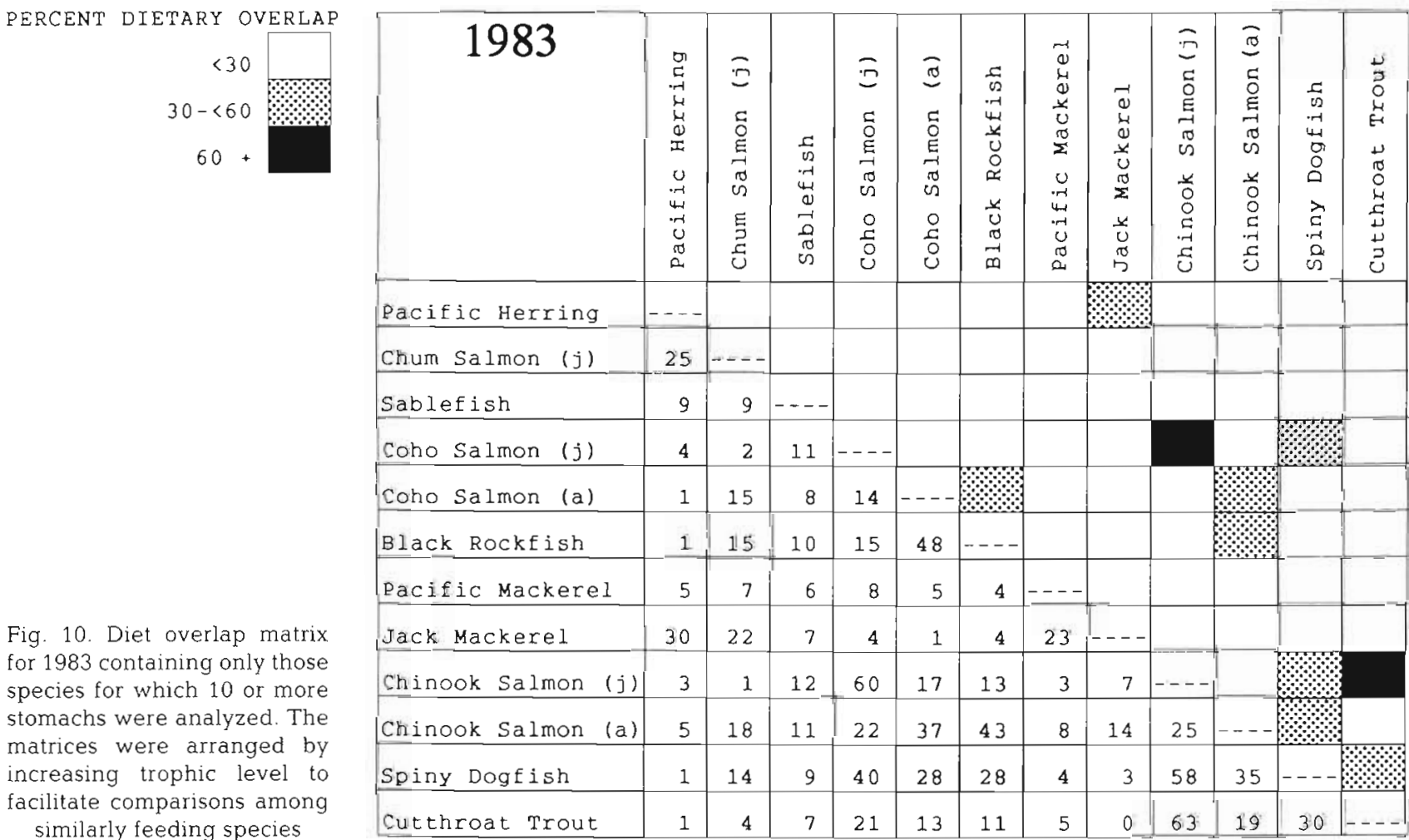


Table 6 . Percent by weight of the major prey categories consumed by pelagic predators during 1984 . See Table 1 for the prey codes listed. j: juvenile; a: adult

\begin{tabular}{|c|c|c|c|c|c|c|c|c|c|c|c|c|c|}
\hline \multirow[t]{2}{*}{ Predators } & \multicolumn{13}{|c|}{ Prey categories } \\
\hline & CNID & CTEN & CEPH & COPE & AMPH & EUPH & DECA & INSE & CHAE & CLUP & SCOR & PLEU & OTHER \\
\hline Market squid & 22.2 & & 1.9 & & 1.9 & 5.6 & 37.0 & & & & & & 31.4 \\
\hline Spiny dogfish & 2.5 & & & & & 33.4 & 0.3 & & & & & 23.0 & 40.7 \\
\hline Coho salmon (j) & & & 0.1 & 0.5 & 1.7 & 8.5 & 11.6 & 14.3 & & 0.7 & 30.5 & 0.8 & 32.1 \\
\hline Coho salmon (a) & & & 3.7 & & 0.2 & 45.2 & 20.4 & 1.4 & & 21.6 & & & 7.4 \\
\hline Chinook salmon (j) & & & 1.2 & 3.5 & 0.5 & 1.6 & 5.9 & 0.4 & 0.1 & 2.3 & 35.0 & 9.8 & 39.7 \\
\hline Chinook salmon (a) & & & 0.8 & & 0.1 & 5.5 & 24.0 & & & 52.0 & 10.1 & & 7.5 \\
\hline Pacific hake & & & & & & 97.7 & 1.5 & & & & & & 0.7 \\
\hline Jack mackerel & & & 0.9 & 0.2 & 0.2 & 79.2 & 7.6 & & 0.3 & & 0.2 & 6.0 & 5.2 \\
\hline Pacific mackerel & 3.7 & 0.6 & & 34.3 & 1.1 & 29.6 & 15.5 & & & & & & 15.2 \\
\hline Black rockfish & 2.1 & 7.1 & & 1.1 & 1.0 & 47.5 & 24.9 & & & & & 0.5 & 15.8 \\
\hline Sablefish & 19.3 & & & & 1.4 & 56.9 & 19.3 & & & & & & 3.0 \\
\hline
\end{tabular}

many species during 1984, yet they were relatively unimportant to juvenile coho and chinook salmon (Table 6). Decapod larvae (mostly pinnotherid and cancrid zoeae and megalopae) contributed substantially to a number of species. Several gelatinous taxa (cnidarians and ctenophores) were also important during 1984.

Overall diet overlap was moderate (mean PSI = 23.2) in 1984. Although there were only 2 overlaps $>60$, as in 1983 , a higher percentage $(31.0 \%$ ) of the PSI values were $>30$ (Fig, 11). Many of the higher overlaps were attributable to the common utilization of euphausiids and decapod larvae by the planktivorous species.

\section{Trophic level and food web analysis}

Trophic level assignments varied among years for the salmonids examined from all 4 years (Table 7). The overall differences between years may be attributed to differences in the primary prey taxa utilized each year. The TLA's for 1981 and 1983 were generally higher than the other 2 years due to a reliance on juvenile fishes (TLA's from 2.8 to 3.3 ) as a main food source for many predators. The lower TLA's seen during 1982 and 1984 reflected the substantial use of euphausiids and decapod larvae (TLA's from 2.3 to 2.5), even among such normally piscivorous species as adult coho and chinook salmon. Indeed, the TLA's for juveniles of
PERCENT DIETARY OVERLAP

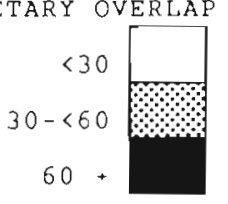

Fig. 11. Diet overlap matrix for 1984 containing only those species for which 10 or more stomachs were analyzed. The matrices were arranged by increasing trophic level to facilitate comparisons among similarly feeding species

\begin{tabular}{|c|c|c|c|c|c|c|c|c|c|c|c|}
\hline 1984 & 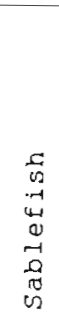 & 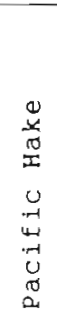 & 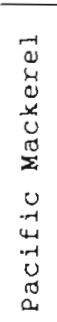 & 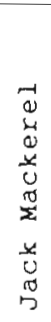 & 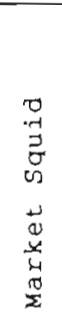 & 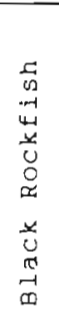 & $\begin{array}{l}\tilde{\Xi} \\
\Xi \\
0 \\
E \\
0 \\
0 \\
0 \\
0 \\
0 \\
0 \\
0\end{array}$ & 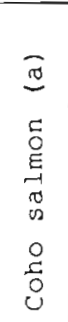 & $\begin{array}{l}\vec{I} \\
0 \\
-4 \\
-4 \\
\sigma \\
0 \\
0 \\
\vec{C} \\
\overrightarrow{0} \\
0 \\
0\end{array}$ & 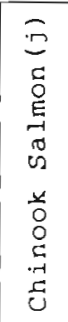 & 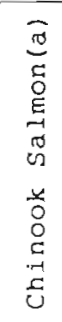 \\
\hline \multicolumn{12}{|l|}{ Sablefish } \\
\hline Pacific Hake & 49 & -- & & & & & & & & & \\
\hline Pacific Mackerel & 41 & 23 & & A & & 2 & & & & & \\
\hline Jack Mackerel & 61 & 70 & 37 & -- & & 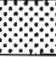 & & 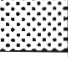 & & & \\
\hline Market Squid & 31 & 5 & 30 & 11 & $\cdots$ & & & & - & & \\
\hline Black Rockfish & 28 & 21 & 33 & 35 & 8 & $-\cdots$ & & & & & \\
\hline Coho salmon (j) & 13 & 9 & 22 & 19 & 16 & 11 & $-\cdots$ & & & & \\
\hline Coho salmon (a) & 34 & 27 & 36 & 34 & 14 & 22 & 24 & --- & & & \\
\hline Soiny Dogeish & 34 & 34 & 25 & 41 & 31 & 8 & 19 & 15 & $-\cdots$ & & \\
\hline Chinook Salmon (j) & 6 & 3 & 23 & 13 & 17 & 12 & 31 & 11 & 24 & $\cdots$ & \\
\hline Chinook Salmon (a) & 10 & 6 & 14 & 13 & 12 & 6 & 44 & 28 & 13 & 22 & \\
\hline
\end{tabular}


Table 7 Trophic level assignments (TLA) for each species by year for pelagic nekton off Washington and Oregon j: juvenile; a: adult

\begin{tabular}{|c|c|c|c|c|c|}
\hline Species & 1981 & 1982 & 1983 & 1984 & $\begin{array}{c}\text { Mean } \\
\text { TLA }\end{array}$ \\
\hline Market squid & 3.84 & - & - & 3.46 & 3.65 \\
\hline Spiny dogfish & 3.75 & 3.58 & 3.97 & 3.75 & 3.76 \\
\hline American shad & 3.26 & - & - & - & - \\
\hline Pacific herring & - & 3.74 & 3.25 & - & 3.49 \\
\hline Northern anchovy & 3.26 & - & - & - & - \\
\hline Sockeye salmon (j) & - & 3.75 & - & - & - \\
\hline Chum salmon $\{j\}$ & - & 3.30 & - & - & - \\
\hline Coho salmon (j) & 3.83 & 3.64 & 3.86 & 3.77 & 3.77 \\
\hline Coho salmon (a) & 3.86 & 3.49 & 3.67 & 3.51 & 3.63 \\
\hline Chinook salmon (j) & 3.93 & 3.90 & 3.92 & 3.92 & 3.92 \\
\hline Chinook salmon (a) & 3.99 & 3.68 & 3.88 & 3.79 & 3.83 \\
\hline Cutthroat trout & 4.01 & 4.04 & 3.99 & - & 4.01 \\
\hline Steelhead (j) & 3.74 & 3.61 & 3.92 & - & 3.76 \\
\hline Pacific hake & - & 3.74 & - & 3.34 & 3.54 \\
\hline Jack mackerel & - & 3.77 & 3.37 & 3.38 & 3.51 \\
\hline Pacific mackerel & - & - & 3.40 & 3.36 & 3.38 \\
\hline Black rockfish & - & 3.50 & 3.87 & 3.46 & 3.61 \\
\hline Sablefish & 3.54 & - & 3.36 & 3.28 & 3.39 \\
\hline
\end{tabular}

these 2 species were substantially higher than those of the adults during all years except 1981 (Table 7). The interannual trends among non-salmonids and the 2 trout species were not as consistent as seen for coho and chinook salmon. In the case of some species (spiny dogfish, Pacific herring, cutthroat trout, and jack mackerel), the TLA's were higher in 1982 than either 1981 or 1983 whereas the opposite was true for steelhead trout and black rockfish

Since the abundances of the dominant species varied by year, we weighted the calculated TLA's for each species by their proportional abundance to arrive at an overall community TLA for each year. In several instances, the number of stomachs available was low relative to the abundance of the predator that year (e.g. most Loligo opalescens stomachs examined during 1982 were empty). In these situations, the mean of the TLA's from the other years (Table 7) was used. These weighted community TLA's for 1981 and 1982 were similar (3.69 and 3.61, respectively), whereas the values for 1983 and 1984 were substantially lower but also quite similar (3.41 and 3.38)

Using the calculated TLA's and data on the relative abundance and inshore-offshore distributions based on occurrences of each species, generalized food webs showing primary ( $>50 \%$ of total weight of stomach contents) and secondary (between 30 and $50 \%$ ) pathways were constructed for each year. Adult northern anchovy were a primary food source for 3 of the highertrophic-level salmonids (TLA's around 4.0) during 1981 (Fig. 12). Juvenile rockfish and other juvenile fishes (sand lance, cottids, flatfish) were important foods for other higher trophic level fishes. The main foods of market squid and spiny dogfish were gelatinous species (the chaetognath Sagitta elegans and the chondrophore Velella velella, respectively). Copepodite and adult stages of calanoid copepods were most important in the diets of the mostly planktivorous (primary carnivore) trophic level.

The 1982 food web was somewhat less complex due to the widespread utilization of euphausiids (Fig. 13). Two euphausiid species, Thysanoessa spinifera and Euphausia pacifica, were important to the diets of many intermediate (TLA's around 3.5) species. Juvenile northern anchovy and other juvenile fishes were major foods of the offshore species of nekton.

Few prey groups were dominant in the 1983 trophic web (Fig. 14). Adult northern anchovy were seldom encountered in the stomachs collected during 1983, but larval and juvenile stages were common in the diets of inshore predators in early summer. Juvenile fishes were important to the offshore food web. Spiny dogfish consumed many juvenile flatfish, which generally prey on epibenthic organisms. Euphausiids were substantially less important to the total food web than during 1982. In addition, one of the major species of euphausiids consumed, Nyctiphanes simplex, did not occur in the diets in either of the previous years Cancer magister megalopae were more important prey for coho salmon in 1983.

The 1984 food web resembled that of 1982 in complexity, with euphausiids being fairly important for most of the nektonic species (Fig. 15). In particular Euphausia pacifica was the main food for several offshore planktivorous fishes. Rockfish juveniles and larval fishes were also important links in the inshore and mid-shelf food webs.

\section{DISCUSSION}

The quantitative descriptions of food habits, dietary overlaps, and trophic levels described in this study are subject to some inherent biases due to the sampling and analytical methods used. Since the stomach collections were pooled over a 2 mo period from all sampling locations, the average overlap values may overestimate or underestimate the true overlaps between 2 species within the same collection, month or area. Although juvenile and adult salmonids were analyzed separately, these stages, as in most of the other species examined, include a wide size range of individuals with potentially varied diets at the extremes. The intent was not to ignore this smaller-scale variability, which has been recognized and discussed elsewhere for most of the predators discussed herein (Peterson et al. 1982, Brodeur et al. 1987, Brodeur \& Pearcy 1990 
TROPHIC LEVEL ASSIGNMENT

TROPHIC LEVEL ASSIGNMENT
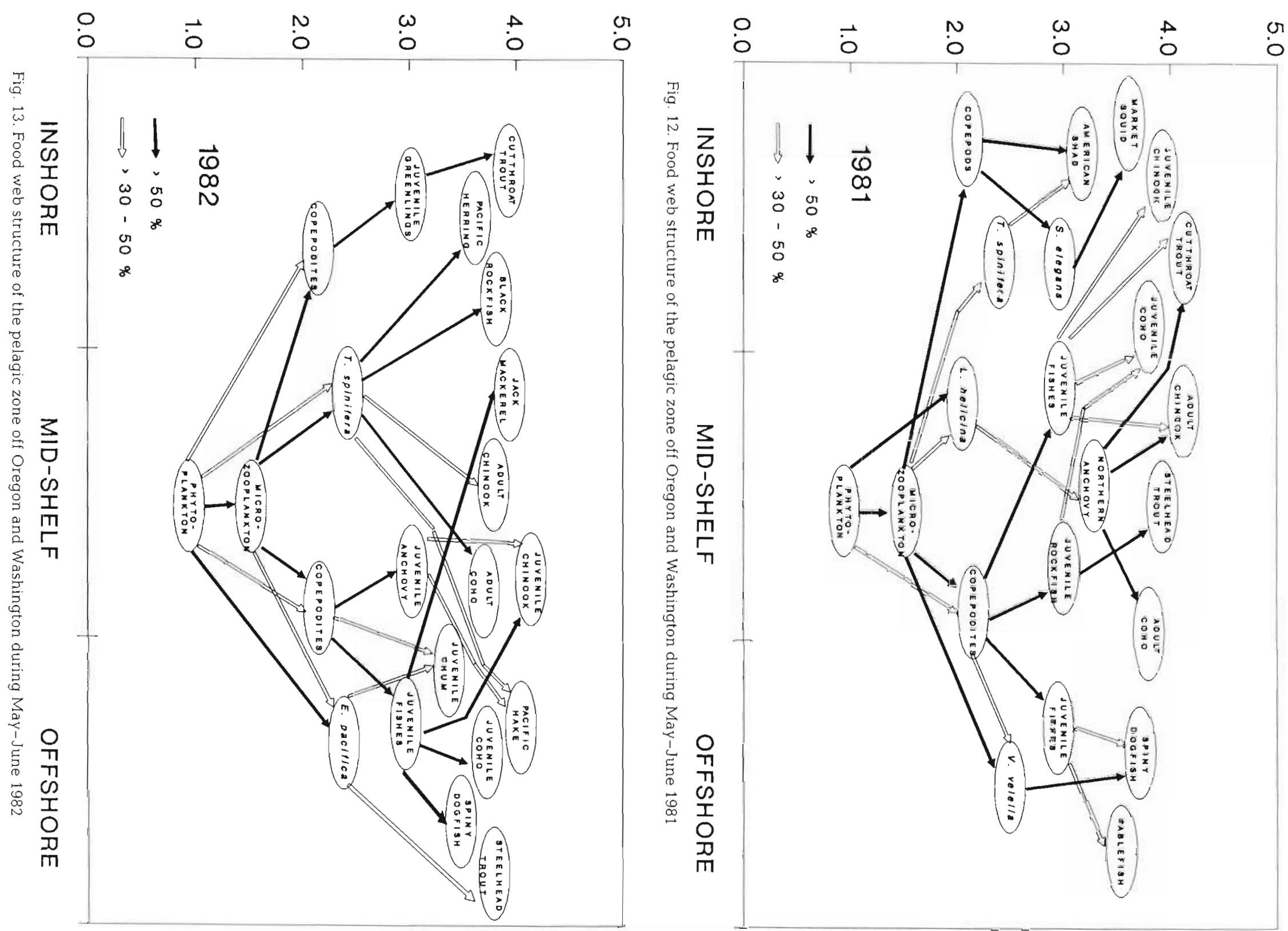


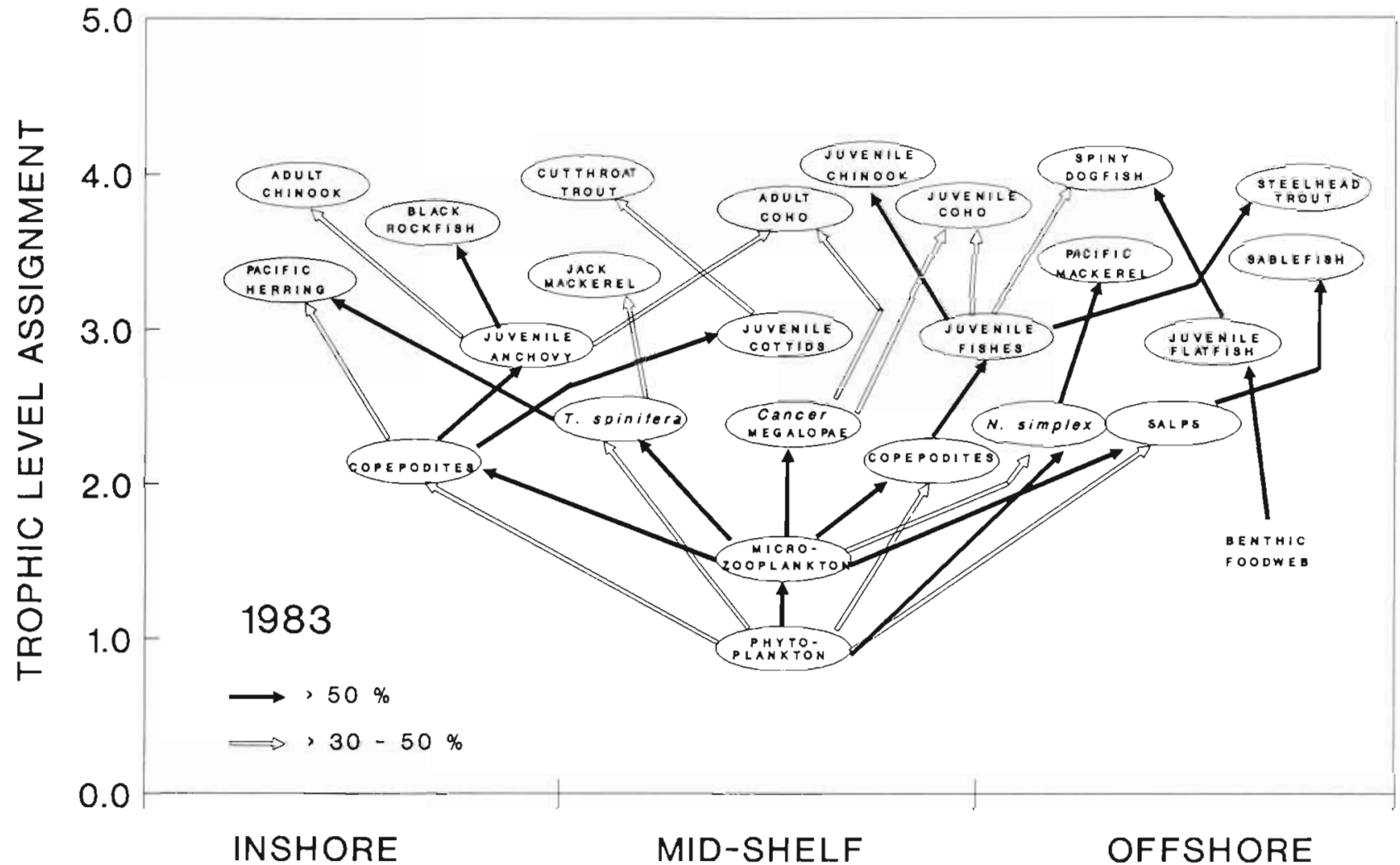

Fig. 14. Food web structure of the pelagic zone off Oregon and Washington during May-June 1983

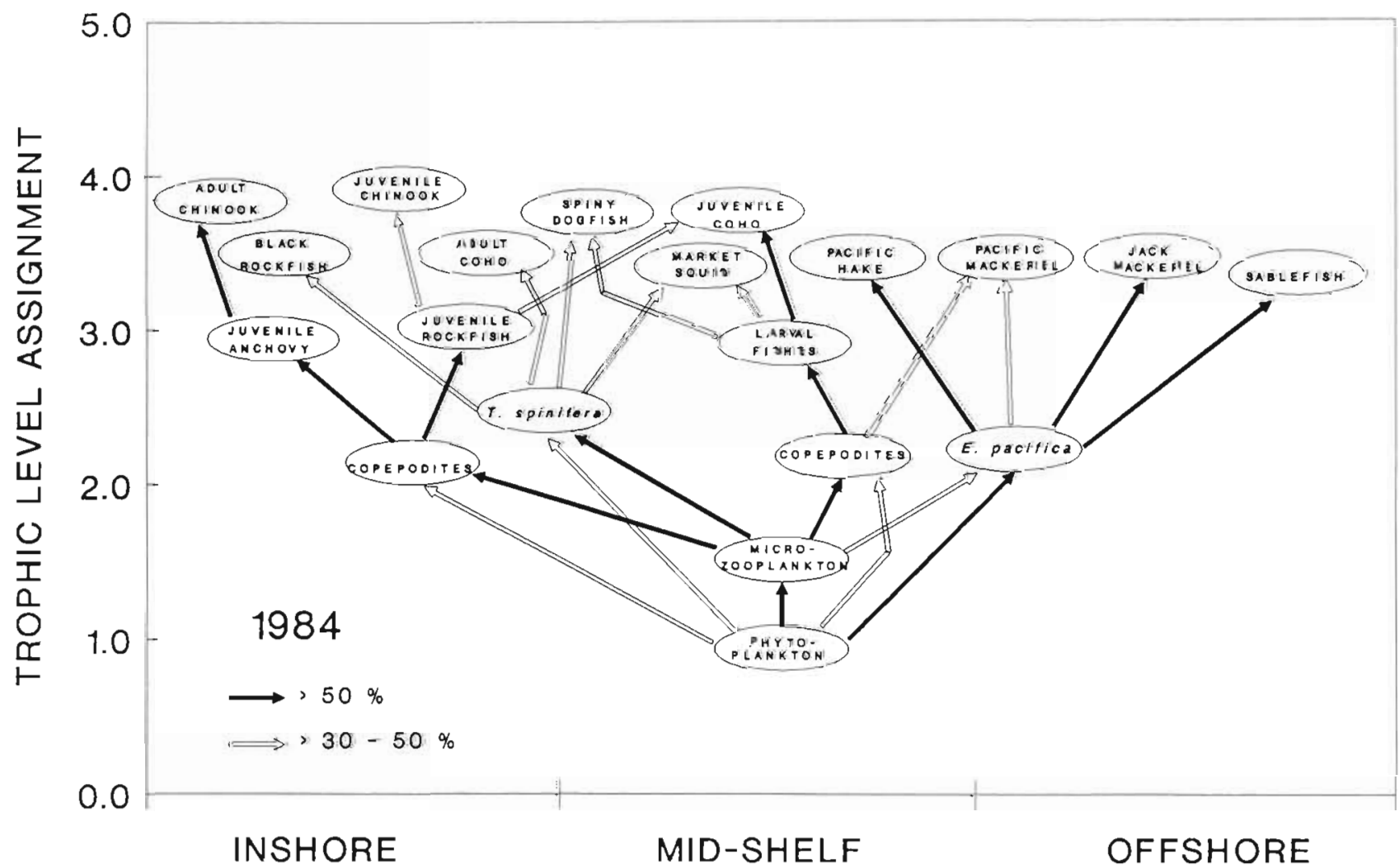

Fig. 15. Food web structure of the pelagic zone off Oregon and Washington during June-July 1984 
Pearcy et al. 1990, Brodeur 1991), but instead was to present on a broader scale the effects of major environmental changes on the diet of these upper-trophiclevel predators. Based on the occurrence of the major prey categories of juvenile salmon and other pelagic predators, the overall diets were generally similar during the 2 mo examined from each year (Brodeur et al. 1987, Brodeur \& Pearcy 1990). Geographic (latitudinal and inshore-offshore) variations in diet composition were also generally less pronounced than interannual differences within a particular species.

In addition, all predators occurring in the pelagic waters sampled may not have been accessible to the sampling gear. Since most collections were made during daytime, predators migrating into the upper $50 \mathrm{~m}$ of the water column during nighttime to feed may have been undersampled (Brodeur \& Pearcy 1986). Two important groups of higher-level predators, marine birds and mammals, were not sampled. Although some data exist in the literature on the feeding habits of these epipelagic predators [e.g. Wiens \& Scott (1975) for marine birds; Kajimura (1984) for marine mammals, and Morejohn et al. (1978) for both groups] these results are not included here because the sampling and diet analysis methodology used in these studies are not directly comparable to those of the present study.

Gelatinous zooplankton constitute another important group of consumers, often representing the highest biomass of epipelagic macro-organisms in purse seine catches in the study area during the summer (Shenker 1984). Some are capable of prodigious feeding rates in neritic waters (Alldredge 1984). Little quantitative data on feeding habits exist for most of the species occurring in the study area, despite the potential impact of their high numbers on nektonic species, either as predators on larval stages or competitors with juvenile and adult stages. Although gelatinous zooplankton have been considered a trophic 'dead end', they can be important components of the pelagic food web serving as major prey items for several nekton species in this study as well as others (see review by Arai 1988).

The general physical and biological characteristics found each year of our study are summarized in Table 8. Interannual variations in food taxa consumed by pelagic predators were related to the varying environmental conditions during this period. For example, euphausiids appeared to be readily available as prey during 1984 and even more so during the relatively strong upwelling year of 1982. During both these years, Euphausia pacifica and Thysanoessa spinifera, species known to be present throughout the summer (Day 1971, Alton \& Blackburn 1972), were the most common prey of many neritic fishes in the study area and were abundant in the plankton (Landry \& Lorenzen 1989, Brodeur 1990). During the $1983 \mathrm{El}$ Niño, however, relatively few individuals of these species were found in plankton tows and stomachs of pelagic predators and the dominant species consumed was a much smaller southern species, Nyctiphanes simplex (Brodeur 1986). Moreover, the overall abundance of zooplankton in 1983 was estimated to be only about 30 to $50 \%$ of the level attained during normal years (Sefton et al. 1984, Miller et al. 1985).

Larvae of many spring-summer spawning fishes were less abundant in 1983 than in previous years. Only northern anchovy appeared to show abovenormal larval abundances (Brodeur et al. 1985). Larval anchovy were first noted as being abundant in stomach contents collected in June 1983, and by September of that year, juvenile anchovy $(50$ to $80 \mathrm{~mm}$ total length) were the dominant prey of many pelagic predators. Although the stomach fullness of juvenile coho salmon was about the same in 1982 and 1983, the rank order of abundance of prey differed between these years, with northern anchovy being the most common fish prey taxon in 1983 (Pearcy et al. 1985).

Table 8. Summary of the interannual variations in physical and biological conditions observed off Washington and Oregon during the study period

\begin{tabular}{|c|c|c|c|c|c|c|c|}
\hline Year & $\begin{array}{l}\text { Upwelling } \\
\text { intensity }\end{array}$ & Temperature & $\begin{array}{l}\text { Chlorophyll } \\
\text { concentration }\end{array}$ & $\begin{array}{c}\text { Nektonic species } \\
\text { composition }\end{array}$ & $\begin{array}{c}\text { Major prey } \\
\text { taxa }\end{array}$ & $\begin{array}{l}\text { Dietary } \\
\text { overlap }\end{array}$ & $\begin{array}{l}\text { Food web } \\
\text { complexity }\end{array}$ \\
\hline 1981 & Weak, late & Warm inshore & Low offshore & $\begin{array}{l}\text { Mixed cold-and } \\
\text { warm-water taxa }\end{array}$ & Fishes & Low & Moderate \\
\hline 1982 & Strong, early & Cool & High & $\begin{array}{c}\text { Northern } \\
\text { cold-water taxa }\end{array}$ & Euphausiids & High & Low \\
\hline 1983 & $\begin{array}{l}\text { Average but } \\
\text { low nutrient }\end{array}$ & Very warm & Very low & $\begin{array}{c}\text { Southern } \\
\text { warm-water taxa }\end{array}$ & None & Very low & High \\
\hline 1984 & Strong, late & Cool inshore & Average & $\begin{array}{l}\text { Mixed cold-and } \\
\text { warm-water taxa }\end{array}$ & $\begin{array}{l}\text { Euphausiids } \\
\text { Decapod larvae }\end{array}$ & Moderate & Moderate \\
\hline
\end{tabular}


Hyperiid amphipods and decapod larvae were also more common in juvenile salmonid diets in 1983 and 1984 than in previous years. These prey may occupy similar trophic levels as euphausiids but due to their relatively small size, much higher abundances may be required to support rapidly growing salmonids and other nekton (Parsons \& LeBrasseur 1970, LeBrasseur 1972). Fulton \& LeBrasseur (1985) hypothesized that during a strong El Niño event, there is a northward shift in the Subarctic Boundary from its normal position off central California to a position off British Columbia, with a resultant decrease in both the overall abundance and size spectrum of zooplankton. An increase in the northward-flowing Davidson Current during the winter of 1982-83 could have caused this shift and led to a predominance of subtropical zooplankton and nekton off Oregon and Washington during 1983 (Miller et al. 1985, Pearcy \& Schoener 1987). Interannual variability in the intensity of the California Current has been postulated as a mechanism which regulates the zooplankton abundance off California (Chelton et al. 1982, Roesler \& Chelton 1987).

Much of the interannual variation in dietary overlap and trophic level may be attributed to variations in a few key prey species. Euphausids represent an important energetic link between the primary producers and many shelf carnivores such as juvenile and adult salmonids, Pacific hake, jack and Pacific mackerel. The predominance of euphausiids in the diets explains the high dietary overlaps among the juvenile salmonids and other co-occuring predators during 1982. These high overlap values, although useful in delineating guilds of similarly feeding fishes, do not necessarily imply competition unless the shared resource is limiting and predators are unable to switch to alternative prey. Conversely, diet overlap would be expected to increase when resources are abundant as several predators concentrate on the most accessible prey. The prevalence of opportunistic feeders in this and other pelagic upwelling ecosystems (Crawford 1987) may buffer against large interannual changes in the abundances of prey organisms.

Unfortunately, we know too little about the biology and life history of the dominant euphausiid species to determine what mechanisms lead to increases in their availability to predators during strong upwelling years. High per capita growth rates (up to $0.01 \mathrm{~mm} \mathrm{~d}^{-1}$ ) and short generation times ( 1 yr) appear to be characteristic of Euphausia pacifica in this productive environment (Smiles \& Pearcy 1971). It is not known, however, whether the responses in growth rate or survival of young euphausiids are rapid enough to increase the available biomass in a matter of months during strong upwelling years. An alternative explanation might be that euphausiids become more aggregated near the surface during high productivity years and thus become more susceptible to pelagic predators.

Because of the importance of euphausiids in the diets of many of the nektonic animals sampled, the average trophic level of adult fishes of potential use to man was between 3 and 4 (i.e. a 2 - to 3 -step food chain). This is similar to the trophic level estimates for most pelagic fishes in other temperate ecosystems (Mearns et al. 1981, Yang 1982, Konchina 1983). This is, however, about 1.5 steps higher than that estimated by Ryther (1969) for pelagic fishes in upwelling areas, which he claimed are dominated by herbivorous clupeid fishes. This view has been challenged by James (1988), who found that clupeids in upwelling regions generally derive little of their nutrition from phytoplankton. This clearly appears to be the case for the pelagic nekton of the northern California Current, where no instances of phytophagy were found (Brodeur et al. 1987).

The link between primary producers and the resident nektonic consumers examined in this study appeared to be less direct during the warm, low productivity El Niño years such as 1983 and other low upwelling years (1981) than during strong upwelling years (1982) The overall food web during these years more closely resembled an oceanic ecosystem than a typical upwelling ecosystem (Ryther 1969, Cushing 1989). However, a summer influx of large numbers of planktivorous southern species (Pacific and jack mackerel) and the comparatively low abundances of piscivorous juvenile and adult salmonids (Pearcy \& Schoener 1987, Pearcy \& Fisher 1990) led to a lower overall trophic level during the El Niño regime.

A key question focusses on the interannual variability in the abundance and grazing rates of the lower trophic levels which we did not examine, such as the microbial and microzooplankton levels, and how these are affected by different levels of production. Any loss of trophic complexity at the higher end of the trophic scale could be made up by additional steps in the lower levels, or conversely, may be more exaggerated by a more direct microbial loop during high productivity years. The only data from the study area pertinent to this question are those of Landry \& Lorenzen (1989) which show a slightly lower biomass of ciliates during August 1983 than June 1982 at one station off Washington, although the overall grazing rate of ciliates was estimated to be much higher in 1983.

One can only speculate whether the more complex food web, together with reduced available food resources and increased abundance of pelagic competitors migrating into this system during 1983, could have led to the reduced production (i.e. low survival of juveniles and small size at return of adults) of salmon that year (Pearcy \& Schoener 1987). Despite much lower abundances of juvenile salmon than in the other years examined here, 
the overall food consumption of juvenile coho and chinook salmon during 1983 was relatively high because of the increased metabolic demand from the elevated temperatures present (Brodeur et al. in press).

The generally accepted current thinking (e.g. Cushing 1989) that upwelling ecosystems always exhibit high primary production and standing stocks of large phytoplankton which form the basis of a short direct food chain (phytoplankton $\rightarrow$ zooplankton $\rightarrow$ fish) needs to be revised. The results of our study suggest that these systems can often more closely resemble stratified oceanic systems dominated by smaller phytoplankton and characterized by a complex food web and potentially lower biomasses of nekton. It should be noted, however, that our sampling occurred within an anomalously warm period in the California Current which began in 1976 ; only 1982 was considered to be a cool year during this period (Landry et al. 1989). Future research examining trophic interactions, total food consumption and abundance of the important pelagic predators will hopefully enable evaluation of the total sustainable fish production in this presently underexploited pelagic ecosystem.

Acknowledgements. We gratefully acknowledge the following for assistance in this study: J. Fisher, A. Chung, and J Shenker (Oregon State University) for assistance in the field, H. Lorz for assistance with the laboratory analysis, and R. C. Francis, W. Wooster, M. Johannes, and 2 anonymous reviewers for providing helpful review comments on earlier versions of the manuscript. This work was supported by the Northwest and Alaska Fisheries Center of the U.S. National Marine Fisheries Service and the Oregon State University Sea Grant College Program.

\section{LITERATURE CITED}

Alldredge, A. L. (1984). The quantitative significance of gelatinous zooplankton as pelagic consumers. In: Fasham, M. J. R. (ed.) Flows of energy and materials in marine ecosystems. Plenum Publishing Corp., New York, p. 407-433

Alton, M. S., Blackburn, C. J. (1972). Diel changes in the vertical distribution of the euphausiids, Thysanoessa spinifera Holmes and Euphausia pacifica Hansen, in coastal waters of Washington. Calif. Fish Game 58:179-190

Anderson, G. C. (1964). The seasonal and geographic distribution of primary productivity off the Washington and Oregon coasts. Limnol. Oceanogr. 9: 284-302

Arai, M. N. (1988). Interactions of fish and pelagic coelenterates. Can. J. Zool. 66: 1913-1927

Bakun, A. (1975). Daily and weekly upwelling indices, west coast of North America, 1967-73. NOAA Tech. Rep. NMFS SSRF-693

Barber, R. T., Smith, R. L. (1981). Coastal upwelling ecosystems. In: Longhurst, A. R. (ed.) Analysis of marine ecosystems. Academic Press, London, p. 31-68

Brodeur, R. D. (1986). Northward displacement of the euphausid Nyctiphanes simplex Hansen to Oregon and Washington waters following the El Nino event of 1982-83. J. Crustacean Biol. 6: 686-692
Brodeur, R. D. (1990). Abundance and distribution patterns of zooplankton along the Oregon and Southern Washington coasts during the summer of 1981. Univ. Wash. Fish. Res. Inst. Tech. Rep. 9003

Brodeur, R. D. (1991). Ontogenetic variations in the type and size of prey consumed by juvenile coho, Oncorhynchus kisutch, and chinook, O. tshawytscha, salmon. Envir. Biol. Fish. 30: 303-315

Brodeur, R D., Francis, R. C., Pearcy, W. G. (in press). Food consumption of juvenile coho and chinook salmon on the continental shelf off Washington and Oregon. Can. J. Fish. Aquat. Sci

Brodeur, R. D., Gadomski, D. M., Pearcy, W. G., Batchelder, H. P., Miller, C. B. (1985). Abundance and distribution of ichthyoplankton in the upwelling zone off Oregon during anomalous El Niño conditions. Estuar. coast. Shelf Sci. 21: 365-378

Brodeur, R. D., Lorz, H. V., Pearcy, W. G. (1987). Food habits and dietary variability of pelagic nekton off Oregon and Washington, 1979-1984. NOAA Tech. Rep. NMFS 57

Brodeur, R. D., Pearcy, W. G. (1986). Distribution and relative abundance of pelagic nonsalmonid nekton off Oregon and Washington, 1979-1984. NOAA Tech. Rep. NMFS 46

Brodeur, R. D., Pearcy, W. G. (1990). Trophic relations of juvenile Pacific salmon of the Oregon and Washington coast. Fish. Bull. U.S. 88: 617-636

Chelton, D. B., Bernal, P. A., McGowan, J. A. (1982). Largescale interannual physical and biological interaction in the California Current. J. mar. Res. 40: 1095-1125

Crawford, R. J M. (1987). Food and population variability in five regions supporting large stocks of anchovy, sardine and horse mackerel. S. Afr. J. mar. Sci. 5: 735-757

Cushing, D. H. (1971). Upwelling and the production of fish. Adv. mar. Biol. 9: 255-334

Cushing, D. H. (1989). A difference in structure between ecosystems in strongly stratified waters and in those that are only weakly stratified. J. Plankton. Res. 11, 1-13

Day, D. S. (1971). Macrozooplankton and small nekton in the coastal waters off Vancouver Island (Canada) and Washington, spring and fall of 1963. U.S. Dept. Commerce, Natl. Mar. Fish. Serv. Spec. Sci. Rept Fish., SSRF-619

Fulton, J. D., LeBrasseur, R. J. (1985). Interannual shifting of the Subarctic boundary and some of the biotic effects on juvenile salmonids. In: Wooster, W. S., Fluharty, D. L. (eds.) El Niño North: Niño effects in the eastern subarctic Pacific. Washington Sea Grant Pub. WSG-WO 85-3. Univ. of Washington, Seattle, p. 237-247

Greene, H. W., Jaksić, F. M. (1983). Food-niche relationships among sympatric predators: effects of level of prey identification. Oikos 40:151-154

Hickey, B. M. (1989). Patterns and processes of circulation. over the continental shelf and slope. In: Landry, M. R., Hickey, B. M. (eds.) Coastal oceanography of Washington and Oregon. Elsevier Science Publ., Amsterdam, p. 41-1.15

Huyer, A. (1976). A comparison of upwelling events in two locations: Oregon and Northwest Africa. J mar Res. 34 : $531-546$

Huyer, A., Smith, R. L. (1985). The signature of El Niño off Oregon. 1982-1983. J. geophys. Res. 90: 7133-7142

James, A. G. (1988). Are clupeid microphagists herbivorous or omnivorous? A review of the diets of some commercially important clupeids. S. Afr. J. mar. Sci. $7 \cdot 161-177$

Kajimura, H. (1984). Opportunistic feeding of the northern fur seal Callorhinus ursinus, in the eastern North Pacific and eastern Bering Sea. NOAA Tech. Rep. NMFS SSRF-779

Kohn, A. J., Riggs, A. C. (1982). Sample size dependence in measures of proportional similarity. Mar. Ecol. Prog. Ser. 9: $147-151$ 
Konchina, Y V. (1983). The feeding niche of the hake, Merluccius gayi, and the jack mackerel, Trachurus symmetricus, in the trophic system of the Peruvian coastal upwelling. J. Ichthyol. 23: 87-98

Landry, M. R., Hickey, B. M. (eds.) (1989). Coastal oceanography of Washington and Oregon. Elsevier Scientific Publications, Amsterdam

Landry, M. R., Lorenzen, C. J (1989). Abundance, distribution, and grazing impact of zooplankton on the Washington shelf In: Landry, M. R., Hickey, B. M. (eds.) Coastal oceanography of Washington and Oregon. Elsevier Science Publ., Amsterdam, p. 175-210

Landry, M. R., Postel, J R., Peterson, W. K., Newman, J. (1989). Broad-scale distributional patterns of hydrographic variables on the Washington/Oregon shelf. In: Landry, M. R., Hickey, B. M. (eds.) Coastal oceanography of Washington and Oregon. Elsevier Science Publ., Amsterdam, p. 1-40

Laurs, R. M. (1967). Coastal upwelling and the ecology of lower trophic levels. Ph.D. thesis. Oregon State University, Corvallis

LeBrasseur, R. J. (1972). Utilization of herbivore zooplankton by maturing salmon. In: Takenouti, A. Y. (ed.) Biological oceanography of the northern Pacific Ocean. Idemitsu Shoten, Tokyo, p. 581-588

Lorz, H. V., Pearcy, W. G. (1975). Distribution of hyperiid amphipods off the Oregon coast. J. Fish. Res. Bd Can. 32: 1442-1447

Lough, R. G. (1975). Dynamics of crab larvae (Anomura, Brachyura) off the central Oregon coast, 1969-1971. Ph.D. thesis. Oregon State University, Corvallis

Mason, J. E. Bakun, A. (1986). Upwelling index update, U.S. West Coast, $33 \mathrm{~N}-48 \mathrm{~N}$ latitude. NOAA Tech. Memo. NMFS-SWFC 67

Mearns, A. J., Young, D. R., Olson, R. J., Schafer, H. A. (1981). Trophic structure and the cesium-potassium ratio in pelagic ecosystems. Calif. coop. ocean. Fish. Invest. Rep. 22: $99-110$

Miller, C. B., Batchelder, H. P., Brodeur, R. D., Pearcy, W. G. (1985). Response of the zooplankton and ichthyoplankton off Oregon to the El Niño event of 1983. In: Wooster, W. S., Fluharty, D. L. (eds.) El Niño North: Niño effects in the eastern subarctic Pacific Ocean. Wash. Sea Grant Pub. WSG-WO-85-3. Univ. of Washington, Seattle, p. 185-187

Morejohn, G. V., Harvey, J. T., Krasnow, L. T (1978). The importance of Loligo opalescens in the food web of marine vertebrates in Monterey Bay, California. Calif. Dep. Fish Game Fish. Bull. 169: 67-98

Mysak, L. A. (1986). El Niño, interannual variability and fisheries in the northeast Pacific Ocean. Can. J. Fish. Aquat. Sci. 43: 464-497

Parsons, T. R., LeBrasseur, R. J. (1970). The availability of food to different trophic levels in the marine food chain. In: Steele, J. H. (ed.) Marine food chains. Oliver and Boyd, Edinburgh, p. 325-343

Pearcy, W. G. (1976). Seasonal and inshore-offshore variations in the standing stocks of micronekton and macrozooplankton off Oregon. Fish Bull. U.S. 74: 70-80

Pearcy, W. G., Brodeur, R.D., Fisher, J. P. (1990). Distribution and biology of juvenile cutthroat trout (Oncorhynchus clarki clarki) and steelhead (O. mykiss) in coastal waters off Oregon and Washington. Fish. Bull. U.S. 88: 697-711

Pearcy, W. G., Fisher, J. P. (1990). Distribution and abundance of juvenile salmonids off Oregon and Washington, 1981-1985. NOAA Tech. Rep. NMFS 93

Pearcy, W., Fisher, J., Brodeur, R., Johnson, S. (1985). Effects of the 1983 El Niño on coastal nekton off Oregon and Washington. In: Wooster, W. S., Fluharty, D. L. (eds.) El Niño North: Niño effects in the eastern subarctic Pacific. Washington Sea Grant Pub. WSG-WO 85-3. Univ. of Washington, Seattle, p. 188-204

Pearcy, W. G., Schoener, A. (1987). Changes in the marine biota coincident with the 1982-1983 El Niño in the northeastern subarctic Pacific Ocean. J. geophys. Res. 92: $14417-14428$

Peterson, W. T., Miller, C. B. (1975). Year-to-year variations in the planktology of the Oregon upwelling zone. Fish. Bull. U.S. 73: 642-653

Peterson, W. T., Miller, C. B. (1977). Seasonal cycle of zooplankton abundance and species composition along the central Oregon coast. Fish. Bull. U.S. 75: 717-724

Peterson, W. T., Brodeur, R. D., Pearcy, W. G. (1982). Food habits of juvenile salmon in the Oregon coastal zone, June 1979. Fish. Bull. U.S. 80: 841-851

Richardson, S. L., Pearcy, W. G. (1977). Coastal and oceanic fish larvae in an area of upwelling off Yaquina Bay, Oregon. Fish Bull. U.S. 75: 125-145

Roesler, C. S., Chelton, D. B. (1987). Zooplankton variability in the California Current, 1951-1982. Calif. coop. ocean. Fish. Invest. Rep. 28: 59-96

Ryther, J. H. (1969). Photosynthesis and fish production in the sea. Science 166: 72-76

Schoener, T W. (1970). Non-synchronous spatial overlap of lizards in patchy habitats. Ecology 51: 408-418

Sefton, H. A., Mackas, D. L., Fulton, J., Ashton, H. (1984). Zooplankton abundance and composition off British Columbia during the 1983 El Niño. Trans. Am. geophys. Un. 65: 909

Shenker, J. M. (1984). Scyphomedusae in surface waters near the Oregon Coast, May-August 1981. Estuar. coast. Shelf Sci. 19: 619-632

Shenker, J. M. (1988). Oceanographic associations of neustonic larval and juvenile fishes and Dungeness crabs off Oregon, 1984. Fish. Bull. U.S. 86: 299-317

Simenstad, C. A., Miller, B. S., Nyblade, C. F., Thornburgh, K., Bledsoe, L. J. (1979). Food web relationships of Northern Puget Sound and the Strait of Juan de Fuca: a synthesis of available knowledge. Rep. EPA-600/7-79-259. EPA, Washington, D.C

Small, L. F., Menzies, D. W. (1981). Patterns of primary productivity and biomass in a coastal upwelling region. Deep Sea Res. 28: 123-149

Smiles, M. C., Pearcy, W. G. (1971). Size structure and growth rate of Euphausia pacifica off the Oregon Coast. Fish. Bull. U.S. $69: 79-86$

Turner, J. T. (1984). The feeding ecology of some zooplankters that are important prey items of larval fish. NOAA Tech. Rep. NMFS 7

Walsh, J. J. (1981). Shelf-sea ecosystems. In: Longhurst, A. R. (ed.) Analysis of marine ecosystems. Academic Press, London, p. 159-196

Wiens, J. A., Scott, J. M. (1975). Model estimation of energy flow in Oregon coastal seabird populations. Condor 77 : 439-452

Yang, J. (1982). A tentative analysis of the trophic levels of North Sea fish. Mar. Ecol. Prog. Ser. 7: 247-252
This article was presented by R. L. Haedrich, St. John's, Nfld, Canada 